\title{
The autophagic inhibition oral squamous cell carcinoma cancer growth of 16-hydroxy-cleroda-3,14-dine-15,16-olide
}

\author{
Ming-Fang Cheng ${ }^{1,2}$, Shian-Ren Lin ${ }^{3}$, Fong-Jen Tseng ${ }^{3,4}$, Yi-Chao Huang ${ }^{5}$, May- \\ Jywan Tsai ${ }^{6}$, Yaw-Syan $\mathbf{F u}^{7}$ and Ching-Feng Weng ${ }^{3}$ \\ ${ }^{1}$ Department of Pathology, Tri-Service General Hospital, National Defense Medical Center, Taipei, Taiwan \\ ${ }^{2}$ Division of Histological and Clinical Pathology, Hualian Armed Forces General Hospital, Hualien, Taiwan \\ ${ }^{3}$ Department of Life Science and Institute of Biotechnology, National Dong Hwa University, Hualien, Taiwan \\ ${ }^{4}$ Department of Orthopedics, Hualien Armed Forces General Hospital, Hualien, Taiwan \\ ${ }^{5}$ Taoyuan Armed Forces General Hospital, Taoyuan, Taiwan \\ ${ }^{6}$ Neural Regeneration Laboratory, Department of Neurosurgery, Neurological Institute, Taipei Veterans General Hospital, \\ Taipei, Taiwan \\ ${ }^{7}$ Department of Biomedical Science and Environmental Biology, Kaohsiung Medical University, Kaohsiung, Taiwan \\ Correspondence to: Ching-Feng Weng, email: cfweng@gms.ndhu.edu.tw \\ Keywords: autophagy, 16-hydroxy-cleroda-3, 14-dine-15, 16-olide, long-leaf polyalthia, oral squamous carcinoma, xenograft tumor \\ Received: March 04, $2017 \quad$ Accepted: May 09, $2017 \quad$ Published: July 04, 2017 \\ Copyright: Cheng et al. This is an open-access article distributed under the terms of the Creative Commons Attribution License 3.0 \\ (CC BY 3.0), which permits unrestricted use, distribution, and reproduction in any medium, provided the original author and source \\ are credited.
}

\section{ABSTRACT}

16-hydroxycleroda-3, 13-dine-15, 16-olide (HCD) isolated from Polyalthia longifolia possesses numerous biological activities. Previous studies have reported that HCD can block phosphorylation activity of cancer cells to inhibit tumor cell growth, but the antitumor activity in oral squamous cell carcinoma is unrevealed. This study investigates the inhibiting effect of HCD on human OSCC cell growth; thereby, developing a new oral cancer drug. In in vitro cultured human OSCC cells (OECM1 and SAS) were employed to test the inhibitory growth of HCD via cell cytotoxic effect using 3-(4, 5-dimethylthiazol2-yI)-2, 5-diphenyltetrazolium bromide (MTT) assay, Western blotting, and further determining of the inhibitory efficacy of tumor growth by a xenograft tumor on BALB/C male nude mice (in vivo test). Under various concentrations of HCD and time course treatments were shown to effectively cause cell death and cell-cycle arrest in OECM1 and SAS cells, which was confirmed via a clinical drug (cisplatin) as a positive control. In addition, HCD induced the autophagic cell death in OECM1 and SAS cells by LC3mediated LC3-I/LC3-II/p62 pathway at the in vitro level. An in vivo assay indicated that HCD could treat oral cancer by deferring tumor growth. These findings provide a favorable assessment for further elucidating the role of HCD that targets autophagic cell death pathways as a potential agent for cancer therapy.

\section{INTRODUCTION}

In oral cancer, squamous cell carcinoma, is the most common in both genders, followed by verrucous carcinoma, and then followed the end of the undiffer-entiated carcinoma, small salivary adenocarcinoma. Oral squamous cell carcinoma (OSCC) in situ may be confined to the basal layer of the epidermis mucous membrane or the outside of the basal layer only invading the shallow microscopic invasive cancer of the connective tissue, but most human OSCC is diagnosed as one invasive cancer. OSCC is also the most common type of head and neck cancer excluding oropharynx and hypopharynx, the mouth of a narrow definition of classification according to the American Joint Committee on inflammation and the International Union Against Cancer [1]. OSCC is locally destructive, may invade soft tissue and bone, and can be extended to the nerves, lymphatic, and blood vessels throughout the 
body that results in cervical lymph node metastasis and distant metastasis [2]. In oral cancer, multiple risk factors including foreign carcinogens play an important role. In Taiwan, occurrences of oral cancer are from chewing betel nut, smoking, and drinking; each of these increases the risks for oral cancer according to the relevant literature statistics. When the subject has all three habits, consequently the relative risk of oral cancer increases by 122.8 times [3].

The anti-cancer chemical drugs including 5-FU, cisplatin, paclitaxel, and Ufur are commonly used to treat oral cancer. However, these chemotherapeutic drugs have side effects such as nausea, vomiting, loss of appetite, decreased immunity, oral ulcers, and other adverse effects. Currently, many herbs including Chinese herbs have been applied for OSCC to dampen the aforementioned problems. Polyalthia longifolia belongs to the family Annonaceae, is popularly known as "ulta Ashok" in India and widely grown in gardens of tropical and subtropical Asia in the regions of the southern part of Taiwan, Pakistan, and Sri Lanka as an evergreen ornamental tree. P. longifolia var. pendula Linn is important in traditional Indian medicine while many part of this tree also have other biological functions [4]. The bark has been reported to have medicinal values to treat skin diseases, fever, hypertension, diabetes, and helminthiasis [5]. A previous study of $P$. longifolia has exhibited anti-inflammatory activity in neutrophils, cytotoxicity towards breast cancer cells, and hepatoma cancer cells [6]. The chemical compounds of $P$. longifolia var. pendula such as diterpenes (clerodane and triterpenes) and aporphine alkaloids have been isolated and investigated for various biological activities. Diterpenoids in the hexane extract of $P$. longifolia seeds shows significant anti-bacterial and anti-fungal activities [7]. Recently, clerodane diterpenes can induce apoptosis of human leukemia HL-60 cells [8]. 16-Hydroxycleroda-3,13dien-15,16-olide (HCD) and its analogs, extracted from the bark of $P$. longifolia exhibits strong antiinflammatory activities [9]; enhanced the expression of cyto-protective HO-1 factor and anti-inflammatory enzyme in microglia [10]; the induction of apoptosis in leukemia K562 cells via both a reduction in histone modifying enzymes PRC2-mediated gene silencing and the reactivation of downstream tumor suppressor gene expressions [11] and via PI3K-Akt pathway and Aurora $B$ resulting in gene silencing and cell cycle disturbance [12]. Our previous studies have demonstrated that HCD could cause apoptosis of two CNS cancer cell lines, N18 and C6, via inhibition of FAK-related signaling pathway and accordingly induced the autophagic cell death through ROS generation and p38/ERK1/2 signaling pathway activation $[13,14]$.

Cisplatin is a traditional anti-cancer agent for treating prostate cancer, bladder cancer, and gastric cancer [15]. Cisplatin has been shown to cause apoptotic cell death [16] and exerts an apoptotic action via mitochondria-mediated activation of caspases [17]. The signals are involved two apoptosome molecules, cytochrome c and Apaf-1, the activation of caspase-9 and caspase-3, downstream molecules leading to mitochondria-mediated apoptosis, and evidenced by cleavage of PARP through the activation of caspase- 3 . Cisplatin is the most efficient drug used for treating OSCC in clinics. It is applied as a positive control in this study to verify the efficacy of testing compounds. This study investigates whether HCD could result in the inhibition of human OSCC cells (OECM1 and SAS) growth by a MTT assay, flow cytometry assay, and Western blotting. Further study was determined HCD that might cause autophagy through the mTOR/PI3K/ Akt/Beclin-1 signaling pathway.

\section{RESULTS}

\section{Effect of HCD and cisplatin on the cell viability of oral cancer cells}

To test the potency of HCD and cisplatin on cell viability of oral cancer cells, OECM1 and SAS cells were incubated with various concentrations of HCD and cisplatin and incubation time courses ( 24 and $48 \mathrm{~h}$ ) to measure the cell viability by a MTT assay. The differences of $24 \mathrm{~h}$ treated with dosedependent fashion were observed. Therefore, the 24 hours' incubation was performed in the subsequent experiments for the efficacy of various concentrations of HCD and cisplatin. Various concentrations $(1,5,10$, 20 , and $50 \mu \mathrm{M}$ ) of HCD were employed to treat the cells for $24 \mathrm{~h}$, the data showed that the cell viabilities of both OECM1 and SAS cells were dose-dependent inhibition $(P<0.05)$ in $5,10,20$, and $50 \mu \mathrm{M}$ of HCD treatment and $\mathrm{IC}_{50}$ of HCD were at the concentrations of 17.79 and $14.79 \mu \mathrm{M}$ in OECM1 and SAS cells, respectively (Figures 1A \& 1B). Additionally, OECM1 and SAS cells were treated with $5,10,20$, and $50 \mu \mathrm{M}$ of cisplatin for $24 \mathrm{~h}$, the results indicated that the cell viabilities of both OECM1 and SAS cells were dose-dependent inhibition $(P<0.05)$ of $\mathrm{HCD}$ treatment and $\mathrm{IC}_{50}$ of cisplatin were at concentrations of 23.44 and $38.91 \mu \mathrm{M}$ in OECM1 and SAS cells, respectively (Figures $1 \mathrm{C} \&$ 1D). Normal BEAS-2B cells were incubated with 1 , 5,10 , and $20 \mu \mathrm{M}$ of $\mathrm{HCD}$ for $24 \mathrm{~h}$ (Figure 1E), there was no effect cell viability of BEAS-2B cells at various concentrations of HCD treatment. While the BEAS-2B cells were treated with 10,20 , and $50 \mu \mathrm{M}$ of cisplatin for $24 \mathrm{~h}$, the data revealed that the $\mathrm{IC}_{50}$ of cisplatin at the concentration of $97.45 \mu \mathrm{M}$ (Figure 1F). Taken together, these results demonstrated that HCD is noncytotoxic to the normal cells and the potency of HCD for the suppressing growth of OECM1 and SAS cells is close to the cisplatin. 
Effect of HCD and cisplatin on the cell cycle of oral cancer cells

To determine the phase of cell cycle in HCD and cisplatin treatments, OECM1 and SAS cells were incubated with various concentrations of HCD and cisplatin, and stained with propidium iodide followed by flow cytometry. OECM1 cells had significantly increased in the $\mathrm{G}_{0} / \mathrm{G}_{1}$ phase $(49.6 \pm 0.1 \%$ to $50.5 \pm 0.2 \%, P<0.05)$ when treated with 1 , 5 , and $10 \mu \mathrm{M}$ of $\mathrm{HCD}$ at $12 \mathrm{~h}$, but no significant difference
OECM1

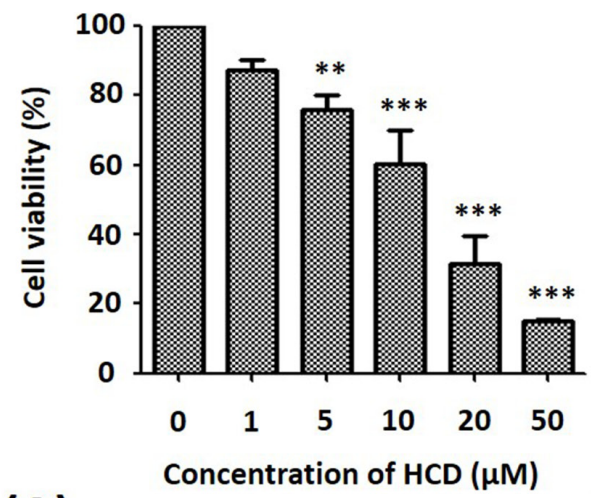

(A)
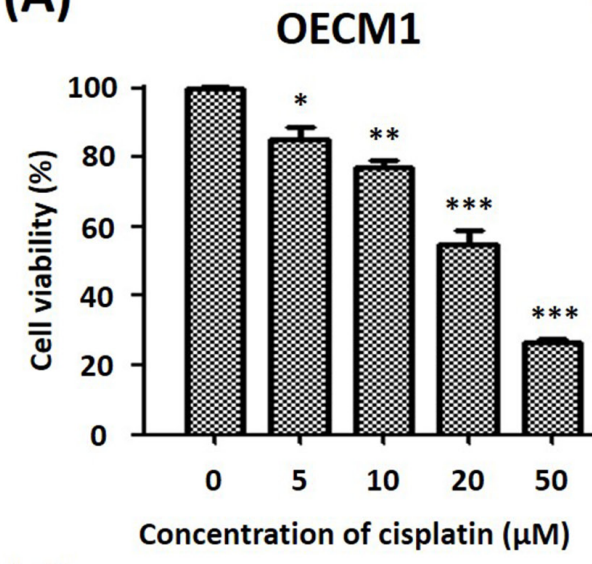

(C)

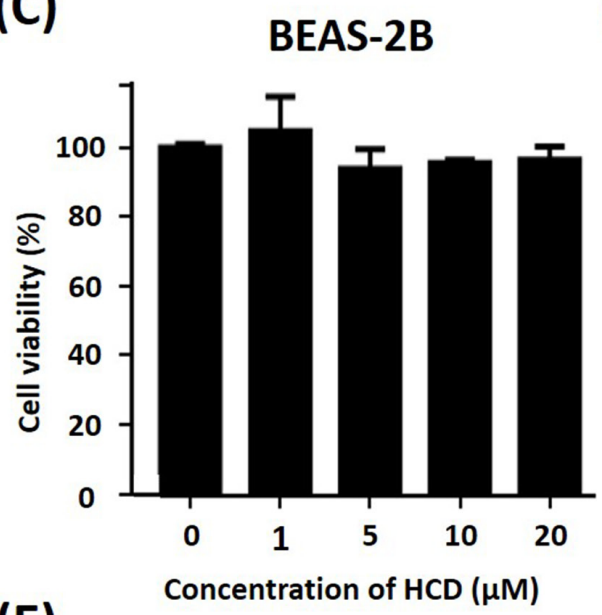

(E)

\section{SAS}

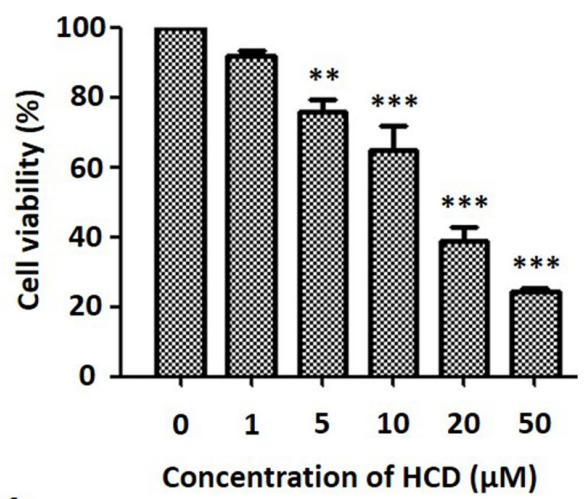

(B)

\section{SAS}

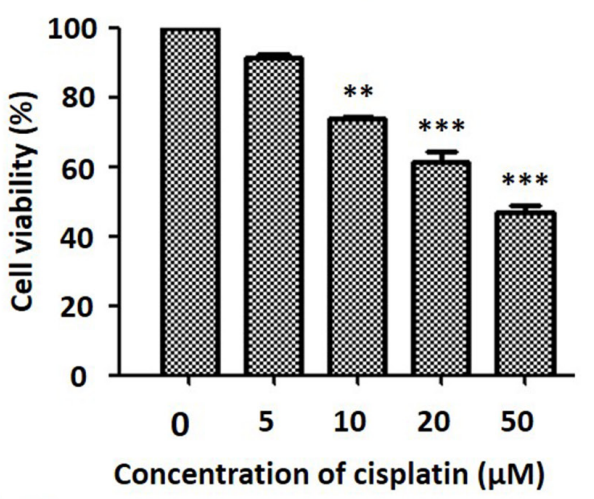

(D)

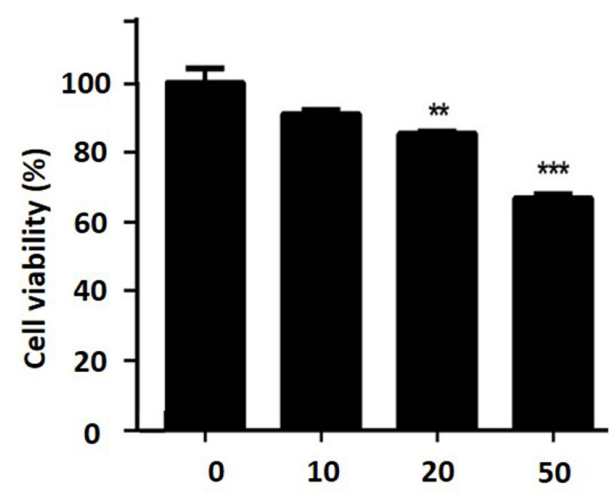

(F)

Figure 1: Alterations of the cell viability of OECM1 and SAS cells after HCD and cisplatin treatments. (A) OECM1, (B) SAS, and (E) BEAS-2Bcells were incubated with 0 to $50 \mu \mathrm{M}$ of HCD for $24 \mathrm{~h}$, and the cell viability was determined by a MTT assay. Cell viability of (C) OECM1, (D) SAS, and (F) BEAS-2Bafter cisplatin treatment for $24 \mathrm{~h}$ are also shown. The data are presented as the mean \pm SE of three independent experiments. $* P<0.05$, ** $P<0.01$ and $* * * P<0.001$ when compared with the untreated control $(0 \mu \mathrm{M})$. 
Table 1: HCD mediated the cell cycle distribution in OECM1 cells

\begin{tabular}{lccccc}
\hline Cell & Dosage $(\boldsymbol{\mu M})$ & Sub G1 $(\%)$ & G0/G1 (\%) & S $(\%)$ & G2/M (\%) \\
\hline OECM1 & 0 & $0.6 \pm 0.1$ & $49.6 \pm 0.1$ & $17.2 \pm 0.6$ & $32.6 \pm 0.2$ \\
$\mathbf{1 2} \mathbf{h}$ & 1 & $1.1 \pm 0.2$ & $48.2 \pm 0.4$ & $18.9 \pm 1.8$ & $31.8 \pm 0.7$ \\
& 5 & $1.4 \pm 0.7$ & $46.8 \pm 0.4$ & $19.3 \pm 1.4$ & $32.5 \pm 2.9$ \\
& 10 & $0.9 \pm 0.4$ & $50.5 \pm 0.2 * *$ & $17.1 \pm 3.0$ & $31.4 \pm 1.5$ \\
$\mathbf{2 4} \mathbf{h}$ & 0 & $1.3 \pm 0.2$ & $48.4 \pm 1.3$ & $14.5 \pm 2.6$ & $35.8 \pm 1.2$ \\
& 1 & $1.3 \pm 0.2$ & $47.4 \pm 2.7$ & $14.4 \pm 2.5$ & $37.0 \pm 0.5$ \\
& 5 & $1.5 \pm 0.5$ & $46.1 \pm 4.0$ & $15.8 \pm 3.6$ & $36.6 \pm 0.2$ \\
& 10 & $2.2 \pm 1.1$ & $38.1 \pm 3.5$ & $13.7 \pm 0.5$ & $46.0 \pm 1.4 * * *$ \\
\hline
\end{tabular}

OECM1 cells were treated with 1,5 , and $10 \mu \mathrm{M}$ of $\mathrm{HCD}$ for 12 and $24 \mathrm{~h}$, respectively and stained with propidium iodide. The results are presented as the mean $\pm \mathrm{SE}$ of three independent experiments. $* * P<0.01$ and $* * * P<0.001$ when compared with the untreated control $(0 \mu \mathrm{M})$.

at $24 \mathrm{~h}$ incubation was found (Table 1). In addition, OECM1 cells treated with 1,5 , and $10 \mu \mathrm{M}$ of HCD for $12 \mathrm{~h}$ had higher percentage of $\mathrm{G}_{0} / \mathrm{G}_{1}$ phase than those of HCD treatment for $24 \mathrm{~h}$. When SAS cells treated with 1 , 5, and $10 \mu \mathrm{M}$ of HCD for 12 and $24 \mathrm{~h}, 24 \mathrm{~h} \mathrm{HCD}$-treated cells were significantly increased in $\mathrm{G}_{0} / \mathrm{G}_{1}$ phase $(37.1 \pm$ $0.4 \%$ to $43.8 \pm 1.4 \%, P<0.05$ ) (Table 2 ). The sub- $\mathrm{G}_{1}$ phase was increased from $1.9 \pm 0.3 \%$ to $3.3 \pm 0.4 \%$ in SAS cells treated with $10 \mu \mathrm{M}$ of HCD for $24 \mathrm{~h}(P<0.05)$. Moreover, the sub- $\mathrm{G}_{1}$ phase was increased from $1.3 \pm 0.2 \%$ to $29.0 \pm$ $4.5 \%$ of OECM1 cells with $20 \mu \mathrm{M}$ of cisplatin treatment for $24 \mathrm{~h}(P<0.05)$ (Table 3$)$. The sub- $\mathrm{G}_{1}$ phase was increased from $1.5 \pm 0.3 \%$ to $18.4 \pm 0.3 \%$ of SAS cells with $20 \mu \mathrm{M}$ of cisplatin treatment for $24 \mathrm{~h}(P<0.05)$. In addition, with 20 $\mu \mathrm{M}$ cisplatin treatment for $12 \mathrm{~h}$ did not show the increase sub- $\mathrm{G}_{1}$ or $\mathrm{G}_{0} / \mathrm{G}_{1}$ phase in OECM-1 and SAS cells (Table 4). When compared to the cell apoptosis of cisplatin treatment, these results revealed that HCD could induce cell death through autophagy in OECM1 and SAS cells.

\section{Effects of HCD on the mTOR protein levels of the autophagy in oral cancer cells}

OECM1 and SAS cells were treated with 1, 5, and $10 \mu \mathrm{M}$ of HCD for $24 \mathrm{~h}$, respectively. In OECM1 cells, the protein levels of mTOR had a significant $(P<0.05)$ decrease in 5 and $10 \mu \mathrm{M}$ of HCD treatments when compared with the untreated control $(0 \mu \mathrm{M})$ (Figure $2 \mathrm{~A})$. When compared with the untreated control, the protein levels of mTOR in SAS cells were no effect of HCD treatments (Figure 2B).

\section{Effects of HCD on the PI3K-classIII protein levels of the autophagy in oral cancer cells}

OECM1 and SAS cells were treated with 1, 5, and $10 \mu \mathrm{M}$ of HCD for $24 \mathrm{~h}$, respectively. In OECM1 cells, the protein levels of PI3K-ClassIII had significant $(P$ $<0.05)$ decrease in 5 and $10 \mu \mathrm{M}$ of HCD treatments when compared with the untreated control (Figure 2C). When compared with the untreated control, the protein levels of PI3K-ClassIII in SAS cells were significantly $(P<0.05)$ down-regulated in $10 \mu \mathrm{M}$ of HCD treatment (Figure 2D).

\section{Effects of HCD on the AMPKa protein levels of the autophagy in oral cancer cells}

OECM1 and SAS cells were treated with 1, 5, and $10 \mu \mathrm{M}$ of HCD for $24 \mathrm{~h}$, respectively. In OECM1 cells, the protein levels of AMPK $\alpha$ had significant $(P<0.05)$ increase in 1,5 and $10 \mu \mathrm{M}$ of HCD treatments when compared with the untreated control (Figure 2E). In SAS cells, the protein levels of AMPK $\alpha$ were also elevated in 1,5 , and $10 \mu \mathrm{M}$ of HCD treatments when compared with the untreated control $(P<0.05)$ (Figure $2 \mathrm{~F})$.

\section{Effects of HCD on the P62 protein levels of the autophagy in oral cancer cells}

OECM1 and SAS cells were treated with 1, 5, and $10 \mu \mathrm{M}$ of HCD for $24 \mathrm{~h}$, respectively. In OECM1 cells, the protein levels of $\mathrm{P} 62$ had significant $(P<0.05)$ increase in 5 and $10 \mu \mathrm{M}$ of HCD treatments when compared with the untreated control (Figure 2G). In SAS cells, the protein levels of P62 had significant $(P<0.05)$ increase in $10 \mu \mathrm{M}$ of HCD treatments when compared with the untreated control (Figure 2H).

\section{Effects of HCD on the Akt protein levels of the autophagy in oral cells}

OECM1 and SAS cells were treated with 1,5 , and $10 \mu \mathrm{M}$ of $\mathrm{HCD}$ for $24 \mathrm{~h}$, respectively. In OECM1 cells, the 
Table 2: HCD mediated the cell cycle distribution in SAS cells

\begin{tabular}{lccccc}
\hline Cell & Dosage $(\boldsymbol{\mu M})$ & Sub G1 $(\%)$ & G0/G1 $(\%)$ & S $(\%)$ & G2/M $(\%)$ \\
\hline SAS & 0 & $1.9 \pm 0.7$ & $37.0 \pm 2.2$ & $28.1 \pm 3.7$ & $33.0 \pm 2.4$ \\
$\mathbf{1 2 ~ h}$ & 1 & $1.7 \pm 0.3$ & $35.3 \pm 3.5$ & $28.1 \pm 3.5$ & $34.8 \pm 2.1$ \\
& 5 & $0.8 \pm 0.3$ & $39.6 \pm 1.2$ & $23.8 \pm 3.1$ & $35.7 \pm 2.3$ \\
& 10 & $1.3 \pm 0.5$ & $39.2 \pm 0.8$ & $21.6 \pm 3.2$ & $37.9 \pm 1.1$ \\
$\mathbf{2 4} \mathbf{h}$ & 0 & $1.9 \pm 0.3$ & $37.1 \pm 0.4$ & $24.4 \pm 1.2$ & $36.6 \pm 3.0$ \\
& 1 & $2.2 \pm 0.1$ & $37.5 \pm 1.6$ & $21.4 \pm 4.7$ & $39.0 \pm 2.7$ \\
& 5 & $2.2 \pm 0.2$ & $36.8 \pm 0.4$ & $27.4 \pm 1.0$ & $33.6 \pm 3.4$ \\
& 10 & $3.3 \pm 0.4 * *$ & $43.8 \pm 1.4 * * *$ & $24.8 \pm 0.3$ & $28.0 \pm 1.9$ \\
\hline
\end{tabular}

SAS cells were treated with 1,5 , and $10 \mu \mathrm{M}$ of $\mathrm{HCD}$ for 12 and $24 \mathrm{~h}$, respectively and stained with propidium iodide. The results are shown as the mean \pm S.E. of three independent experiments. $* * P<0.01$ and $* * * P<0.001$, when compared with the untreated control $(0 \mu \mathrm{M})$.

Table 3: Cisplatin mediated the cell cycle distribution in OECM1 cells

\begin{tabular}{lccccc}
\hline Cell & Dosage $(\boldsymbol{\mu M})$ & Sub G1 $(\mathbf{\%})$ & G0/G1 (\%) & S $(\%)$ & G2/M $(\%)$ \\
\hline OECM1 & 0 & $0.8 \pm 0.2$ & $48.0 \pm 0.5$ & $19.7 \pm 2.4$ & $31.5 \pm 0.3$ \\
$\mathbf{1 2} \mathbf{~ h}$ & 5 & $1.3 \pm 0.5$ & $41.3 \pm 1.9$ & $24.0 \pm 0.9$ & $33.5 \pm 0.5$ \\
& 10 & $0.6 \pm 0.1$ & $38.8 \pm 0.4$ & $28.7 \pm 0.9$ & $32.0 \pm 2.1$ \\
& 20 & $0.7 \pm 0.1$ & $46.9 \pm 0.3$ & $26.0 \pm 3.5$ & $26.4 \pm 0.9$ \\
$\mathbf{2 4} \mathbf{~ h}$ & 0 & $1.3 \pm 0.2$ & $45.0 \pm 3.8$ & $21.3 \pm 2.1$ & $32.4 \pm 3.5$ \\
& 5 & $2.3 \pm 0.4$ & $34.6 \pm 4.7$ & $41.4 \pm 5.7^{* *}$ & $21.7 \pm 2.6$ \\
& 10 & $9.4 \pm 2.1$ & $47.8 \pm 2.9$ & $25.6 \pm 2.1$ & $17.2 \pm 3.8^{*}$ \\
& 20 & $29.0 \pm 4.5^{* * *}$ & $34.2 \pm 4.4$ & $18.4 \pm 0.4$ & $18.4 \pm 4.9^{*}$ \\
\hline
\end{tabular}

OECM1 cells were treated with 5, 10, and $20 \mu \mathrm{M}$ of Cisplatin for 12 and $24 \mathrm{~h}$, respectively and stained with propidium iodide. The results are shown as the mean \pm S.E. of three independent experiments. $* P<0.05, * * P<0.01$ and $* * * P<$ 0.001 , compared with the untreated control $(0 \mu \mathrm{M})$.

protein levels of Akt had significant $(P<0.05)$ decrease in $10 \mu \mathrm{M}$ of HCD treatments when compared with the untreated control (Figure 3A). When compared with the untreated control, the protein levels of Akt in SAS cells were significantly $(P<0.05)$ decreased in 5 and $10 \mu \mathrm{M}$ of HCD treatments (Figure $3 \mathrm{~B}$ ).

\section{Effects of HCD on the beclin-1 protein levels of the autophagy in oral cancer cells}

OECM1 and SAS cells were treated with 1, 5, and $10 \mu \mathrm{M}$ of HCD for $24 \mathrm{~h}$, respectively. In OECM1 cells, the protein levels of Beclin-1 had significant $(P<0.05)$ decrease in $10 \mu \mathrm{M}$ of HCD treatments when compared with the untreated control (Figure 3C). In SAS cells, the protein levels of Beclin-1 were significantly decreased in 5 and $10 \mu \mathrm{M}$ of HCD treatments when compared with the untreated control $(P<0.05)$ (Figure 3D).

\section{Effects of HCD on the cyclin D protein levels of the autophagy in oral cancer cells}

OECM1 and SAS cells were treated with 1, 5, and $10 \mu \mathrm{M}$ of HCD for $24 \mathrm{~h}$, respectively. In OECM1 cells, the protein levels of cyclin D had significant decrease in 5 and $10 \mu \mathrm{M}$ of HCD treatments when compared with the untreated control $(P<0.05)$ (Figure 3E). In SAS cells, the protein levels of cyclin $\mathrm{D}$ had significant decrease in $10 \mu \mathrm{M}$ of HCD treatments when compared with the untreated control $(P<0.05)$ (Figure 3F). 
Table 4: Cisplatin mediated the cell cycle distribution in SAS cells

\begin{tabular}{|c|c|c|c|c|c|}
\hline Cell & Dosage $(\boldsymbol{\mu M})$ & Sub G1 (\%) & G0/G1 (\%) & S (\%) & G2/M (\%) \\
\hline SAS & 0 & $1.3 \pm 0.2$ & $39.3 \pm 1.7$ & $24.3 \pm 3.8$ & $35.1 \pm 1.3$ \\
\hline \multirow[t]{3}{*}{$12 \mathrm{~h}$} & 5 & $1.1 \pm 0.1$ & $35.7 \pm 4.1$ & $28.5 \pm 2.2$ & $34.7 \pm 0.8$ \\
\hline & 10 & $1.0 \pm 0.1$ & $43.2 \pm 3.7$ & $24.8 \pm 6.2$ & $31.0 \pm 1.8$ \\
\hline & 20 & $2.5 \pm 1.1$ & $51.6 \pm 1.4$ & $22.0 \pm 6.6$ & $23.9 \pm 2.6$ \\
\hline \multirow[t]{4}{*}{$24 \mathrm{~h}$} & 0 & $1.5 \pm 0.3$ & $41.3 \pm 6.4$ & $25.8 \pm 2.9$ & $31.4 \pm 5.1$ \\
\hline & 5 & $5.1 \pm 2.3$ & $59.0 \pm 0.9^{*}$ & $22.0 \pm 5.1$ & $13.9 \pm 2.8^{* *}$ \\
\hline & 10 & $9.7 \pm 0.9^{*}$ & $54.9 \pm 2.9$ & $17.6 \pm 4.6$ & $17.7 \pm 0.6^{*}$ \\
\hline & 20 & $18.4 \pm 3.1^{* * *}$ & $44.8 \pm 4.1$ & $16.7 \pm 2.8$ & $20.0 \pm 1.1$ \\
\hline
\end{tabular}

SAS cells were treated with 5,10, and $20 \mu \mathrm{M}$ of Cisplatin for 12 and $24 \mathrm{~h}$, respectively and stained with propidium iodide. The results are shown as the mean \pm S.E. of three independent experiments. $* P<0.05, * * P<0.01$ and $* * * P<0.001$, when compared with the untreated control $(0 \mu \mathrm{M})$.

\section{Effects of HCD on the LC3-I \& II protein levels of the autophagy in oral cancer cells}

OECM1 and SAS cells were treated with 1,5 , and 10 $\mu \mathrm{M}$ of HCD for $24 \mathrm{~h}$, respectively. In OECM1 cells, the protein levels of LC3-I \& II had significant $(P<0.05)$ increase in 5 and $10 \mu \mathrm{M}$ of $\mathrm{HCD}$ treatments when compared with the untreated control. In SAS cells, the protein levels of LC3-I \& II had significant $(P<0.05)$ increase in $10 \mu \mathrm{M}$ of HCD treatments when compared with the untreated control (Figure 4). From all Western blots data demonstrated that HCD indeed caused cell death via autophagy in OECM1 and SAS cells.

\section{Suppressive effects of HCD on the tumor of SAS cells-bearing xenograft mice}

To validate anti-tumor efficacy of HCD on the SAS cells-bearing xenograft mice, various dosages of HCD and cisplatin (reference drug as a positive control) were employed to test in SAS cells-xenograft mice. We also monitored the body weight of nude mice during HCD and cisplatin treatments and the result showed no significant change among the control and treated groups (data not shown). The tumor volume of SAS cells xenograft mice was significantly affected by HCD treatment (Figure 5A). After treatment for 2 weeks, the average tumor sizes were 629,373 , and $277 \mathrm{~mm}^{3}$ in the $2.0,6.5$, and $19.5 \mathrm{mg} / \mathrm{kg} \mathrm{B}$.wt of HCD treated groups, respectively. The average tumor size was $506 \mathrm{~mm}^{3}$ in the 0.1 $\mathrm{mg} / \mathrm{kg}$ cisplatin treated group. However, the average tumor size was $836 \mathrm{~mm}^{3}$ in the control group. The rates of inhibition by HCD treatment were $24.8,55.4$, and $66.9 \%$ in the 2.0, 6.5, and $19.5 \mathrm{mg} / \mathrm{kg}$ B.wt of HCD treated groups, respectively; and was $39.4 \%$ in $0.1 \mathrm{mg} / \mathrm{kg}$ cisplatin treated group.

The macroscopic appearance of tumor in xenograft nude mice had smaller tumor weight when treated with $2.0,6.5$, and $19.5 \mathrm{mg} / \mathrm{kg}$ B.wt of HCD as compared with the untreated control group (Figure 5B \& 5C). The tumor volume of nude mice had significantly decreased in 2.0, 6.5 , and $19.5 \mathrm{mg} / \mathrm{kg} \mathrm{B.wt}$ of HCD treated groups when compared with the untreated control group $(P<0.05)$ (Figure 5D). The histological changes in tumor tissues were assessed by H\&E staining to determine the tumor cell arrangement density. The cell arrangements of control group were denser than those of HCD treated groups (Figure 6). These results revealed that HCD suppressed tumor growth in SAS cells-bearing nude mice, suggesting long-leaf Polyalthia possesses the potential for anti-tumor efficacy in human oral squamous cell cancer.

\section{DISCUSSION}

HCD was obtained from $P$. longifolia and induced differential consequences from an in vitro assay such as cell toxicity, cell cycle, and autophagy signaling pathways in different types of OSCC cell lines (OECM1 and SAS). In BEAS-2B normal cell treated with various concentrations of HCD had no effect on cell viability, which indicated that HCD is non-cytotoxic (Figure 1E). When compared to the cytotoxicity of cisplatin in OECM1 and SAS cells with $\mathrm{IC}_{50}$ values of 23.44 and $38.91 \mu \mathrm{M}$, respectively (Figure $1 \mathrm{C} \& 1 \mathrm{D}) ; \mathrm{HCD}$ had moderate $\mathrm{IC}_{50}$ values of 17.79 and $14.79 \mu \mathrm{M}$ for cell viability, respectively (Figure 1A\&1B); and induced OECM1 and SAS cell death with a dose-dependent manner. Increases in $\mathrm{G}_{0} / \mathrm{G}_{1}$ phase cell cycle arrest with increasing doses of HCD treatments in OECM1 and SAS cells were apparent (Tables $1 \& 2$ ). There was no increase of cells in the sub- $\mathrm{G}_{1}$ phase with various doses of $\mathrm{HCD}$. The results also showed that HCD activated the protein levels of LC3-I \& II (Figure 4). And also, it is well documented that LC3-I and LC3-II both proteins are involved in the development of autophagy and play an important role during autophagy [18]. Notably, autophagy can have two opposing effects, namely cytoprotection and autophagic 
cell death [19]. Autophagy is a catabolic pathway used by cells to support metabolism in response to starvation and to clear damaged proteins and organelles in response to stress [20]. Moreover, autophagy has been reported to play roles in anticancer therapy in multiple cancers [21]. In the present results showed that HCD has an inhibitory role on

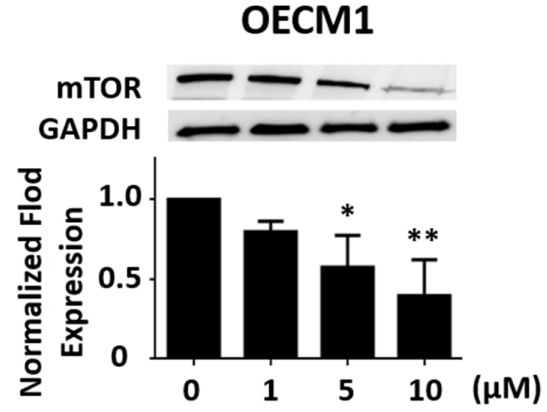

(A)

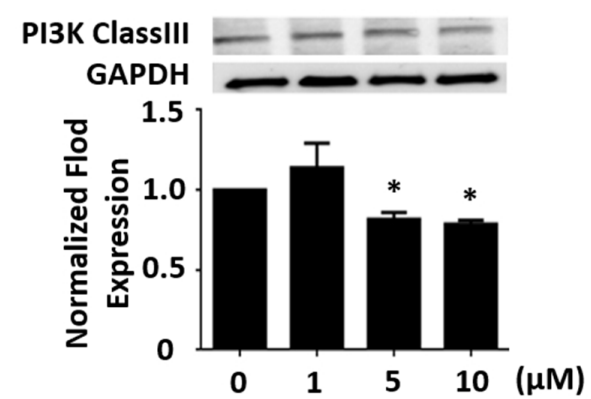

(C)

Concentration of HCD
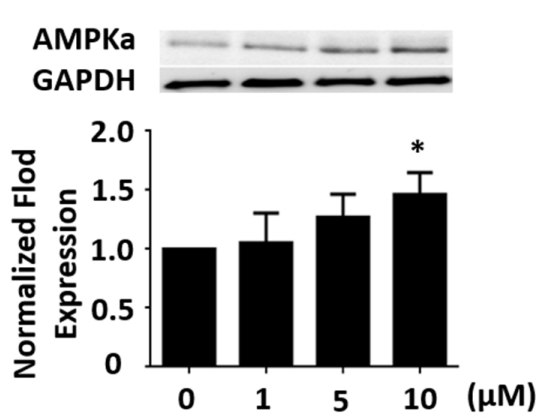

(E)
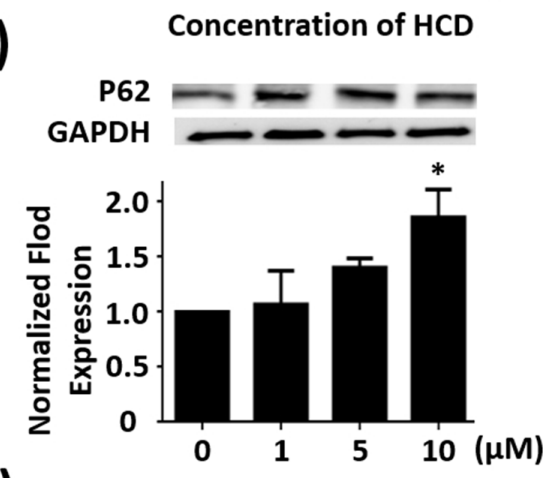

(G)

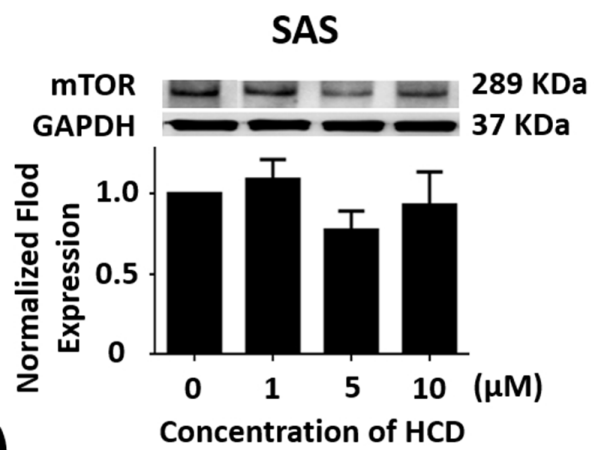

(B)

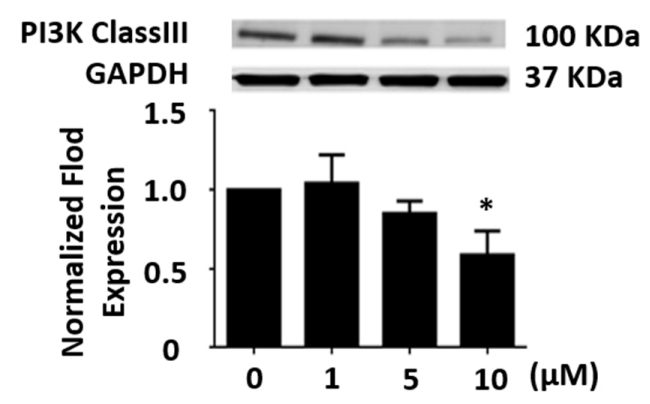

(D)

Concentration of HCD
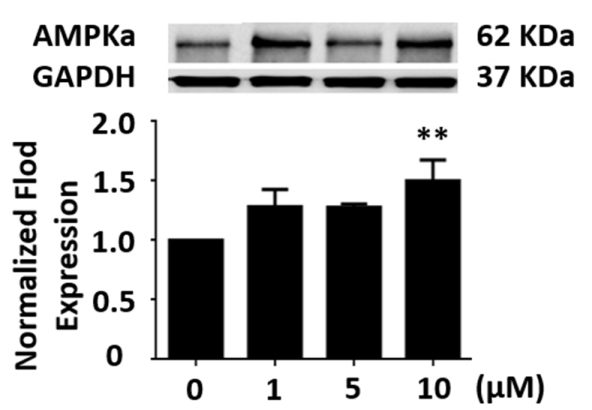

(F)

Concentration of HCD
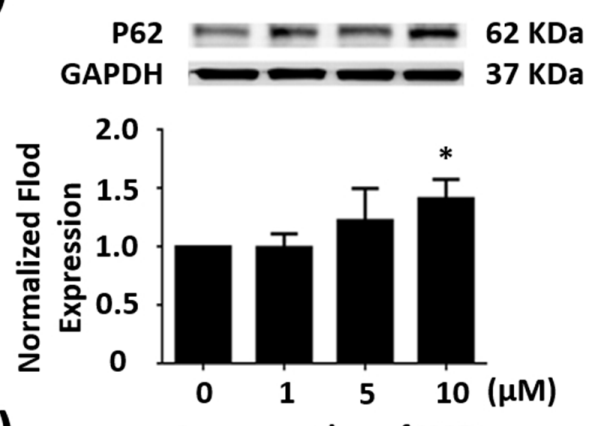

(H)

Concentration of HCD

Figure 2: Altered protein levels of mTOR, PI3K Class III, AMPKa, and P62 of OECM1 and SAS cells treated with HCD. OECM1 and SAS cells were treated with 1, 5, and $10 \mu \mathrm{M}$ of HCD for $24 \mathrm{~h}$. Cells were lysed in RIPA buffer for the Western blot. Quantization of the expressions of (A and B) mTOR, (C and D) PI3K Class III, (E and F) AMPKa, and (G and $\mathbf{H})$ P62 protein levels were performed, respectively. The results were presented as the mean $\pm \mathrm{SE}$ of three independent experiments. $* P<0.05$ and $* * P<0.01$ when compared with the untreated control $(0 \mu \mathrm{M})$. 
oral cancer cells partially via the induction of cell cycle arrest and cell death by autophagy.

In this study, clinical drug cisplatin, as a reference control, exerts its apoptotic action by the mitochondriamediated activation of caspases [16]. Moreover, the mechanism of cisplatin action on apoptosis cell death has been elucidated [17]. Apoptosis has two apoptosome molecules, cytochrome c and Apaf-1, the activation of caspase- 9 and caspase-3, downstream molecules leading to mitochondria-mediated apoptosis, and is evidenced by the cleavage of PARP through the activation of caspase- 3 and were detected after cisplatin-treated. In both Tables $3 \& 4$ show that treatment with $20 \mu \mathrm{M}$ of cisplatin could remarkably induce higher sub- $\mathrm{G}_{1}$ phase cells in OECM1 and SAS cells, revealing that cisplatin-treated lead to cell death by apoptosis $[15,22]$. This further confirmed that HCD treatments did not affect any dramatic sub- $\mathrm{G}_{1}$ change, implying that the cell death of HCD-treated in OECM1 cells might be through different pathways via a non-apoptotic fashion. While SAS cells treated with HCD

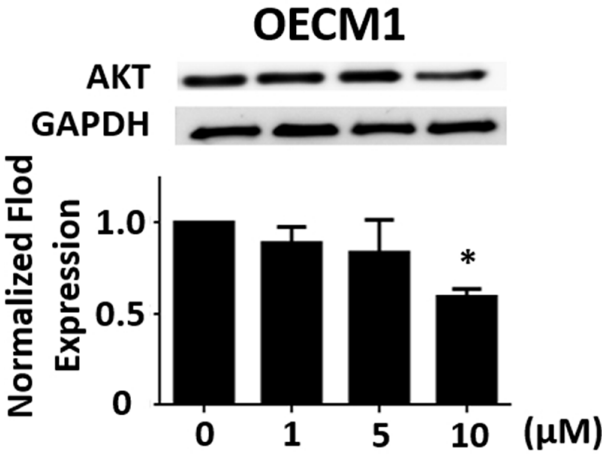

(A)

Concentration of HCD

(B)
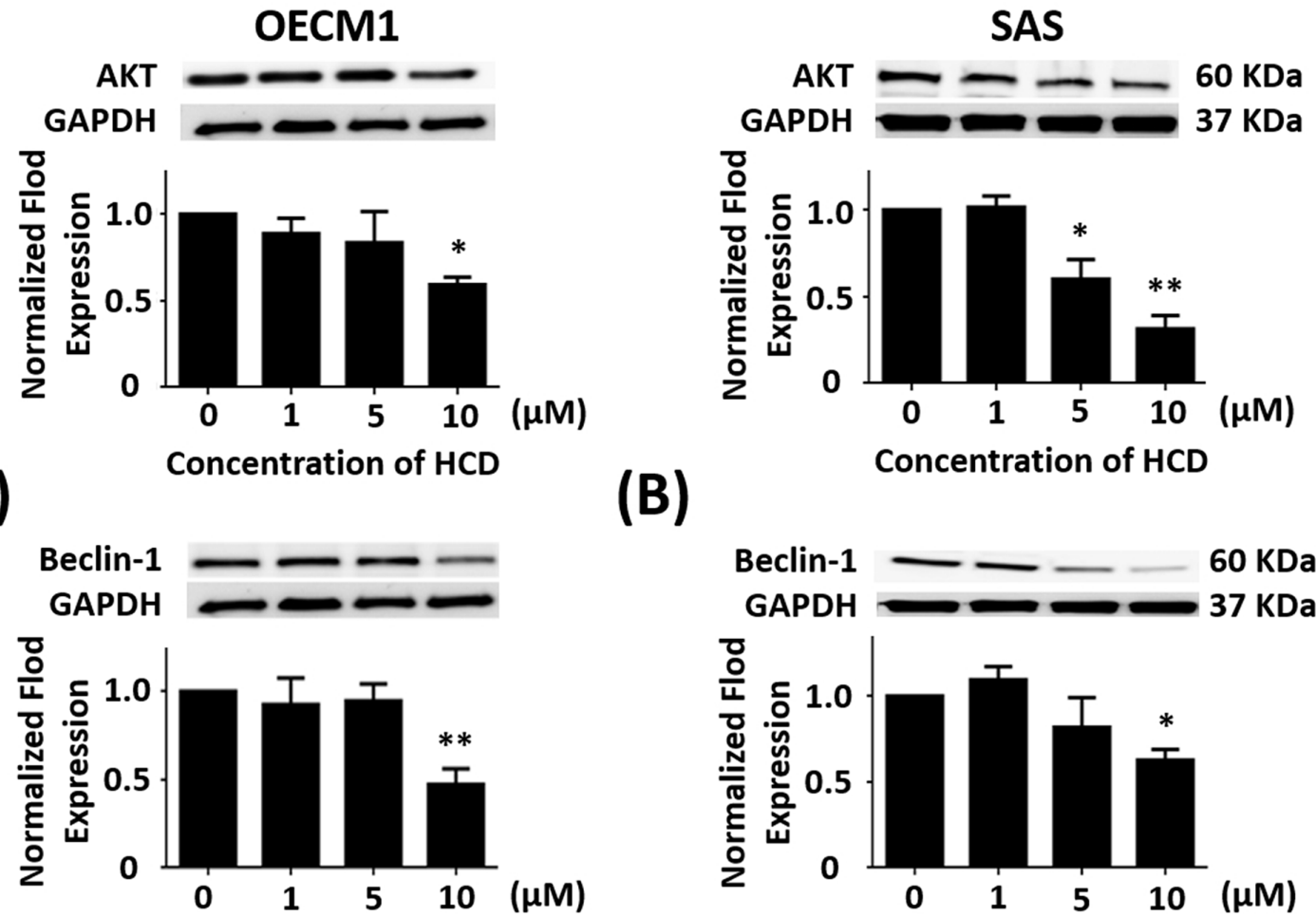

(C)

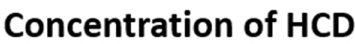

(D)
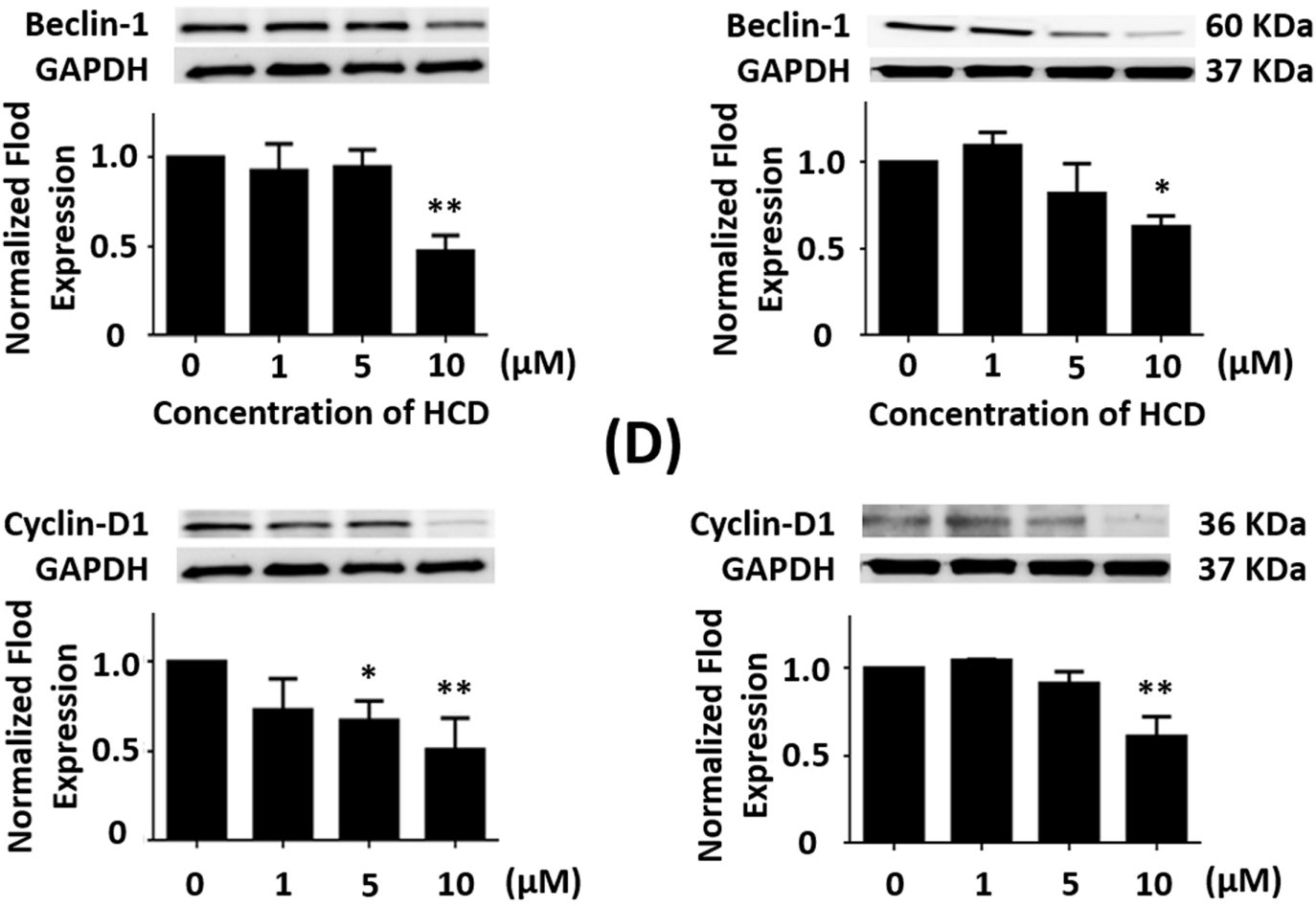

(E)

Concentration of HCD

(F)

Figure 3: Altered protein levels of Akt, Beclin-1, and cyclin D1 of OECM1 and SAS cells treated with HCD. OECM1 and SAS cells were treated with 1, 5, and $10 \mu \mathrm{M}$ of HCD for $24 \mathrm{~h}$. Cells were lysed in RIPA buffer for Western blot. Quantization of the expressions of (A and B) Akt, (C and D) Beclin-1, and (E and F) cyclin D1 protein levels were performed, respectively. The results were presented as the mean \pm SE of three independent experiments. ${ }^{*} P<0.05$ and ${ }^{* *} P<0.01$ when compared with the untreated control $(0 \mu \mathrm{M})$. 
showed cell cycle arrest represented as cell autophagy, suggesting the cause of HCD on cell death of SAS is through signal pathway via an autophagic manner.

OECM1 is a non-tumorigenic human gingival squamous carcinoma cell line with a p53 missense mutation at codon 173 [23]. Unlike OECM1, SAS, a tongue carcinoma cell line, is a tumorigenic cell line with wild-type p53 activity [24]. In researching OSCC chemotherapy, cucurbitacin E, a natural compound from family Cucurbitaceae, could be a potent chemopreventive agent against OSCC [18]. Andrographolide, extracted from Andrographis paniculata, could enhance radio-sensitivity in oral cancer [25]. Again, curcumin could decrease DNA adducts, induce NF- $\kappa$ B activity, and delay tumorigenesis in oral cancer cells [26]. Recently,
OECM1 and SAS cells were triggered via the autophagic pathway with the mammalian target of rapamycin (mTOR)/phosphatidylinositol 3 kinase (PI3K)/Akt/Atg6 (Beclin-1)/p70 ribosomal protein S6 kinase (p70S6K) signal pathways after tetrandrine treatment [18]. The Ras/RAF/MEK/ERK signaling pathways activated the proliferation and death of cancer cells are frequently associated with the induction of autophagy [27]. Of note, autophagy is a catabolic process of the eukaryotic cells [28] and has been extensively studied in cancer therapy. However, the results of cell cycle analysis showed no sub- $\mathrm{G}_{1}$ increase in two cell lines after HCD treatment, the upstream apoptosis signaling pathway cannot be excluded that the interaction of autophagy and apoptosis is frequently observed. Beclin-1, p53, caspase-3, 6, and
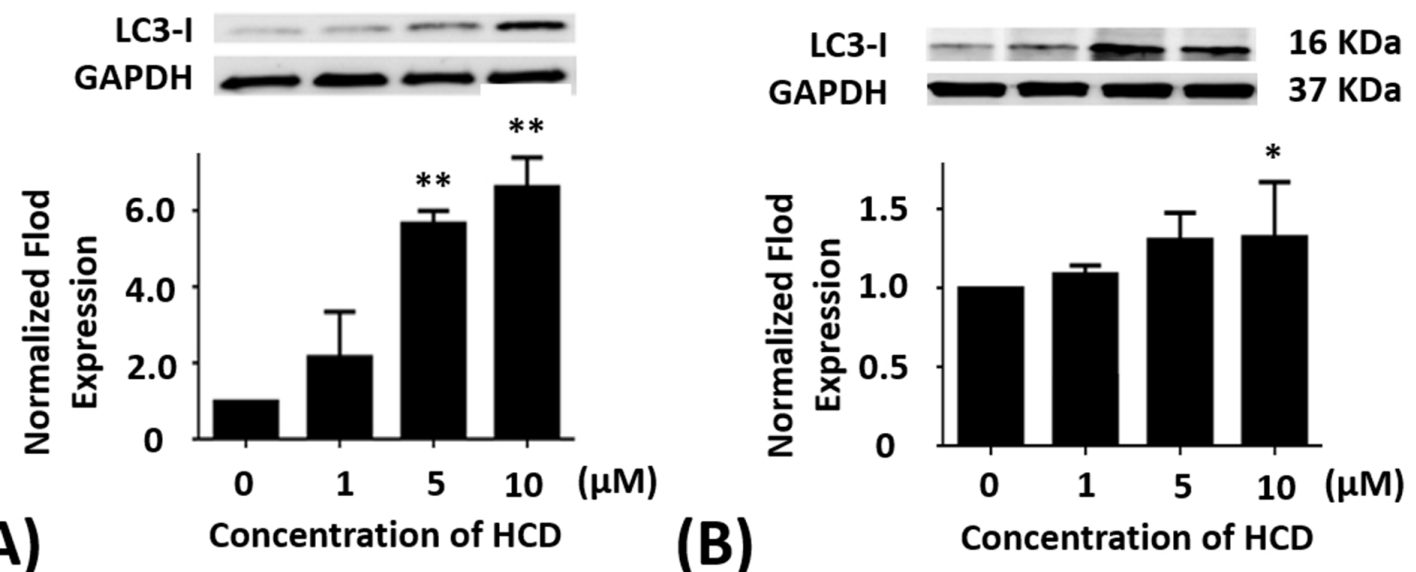

OECM1

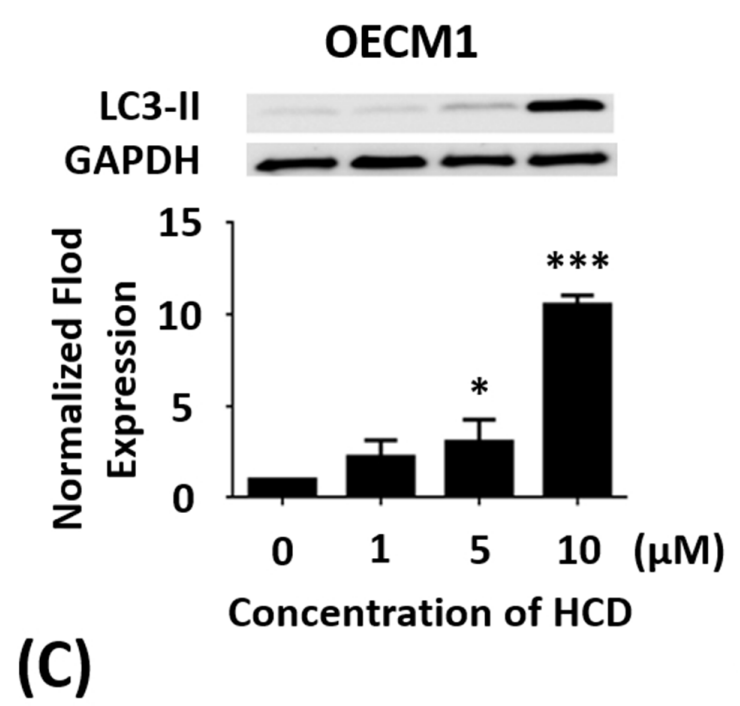

(C)

\section{Concentration of HCD}

(B)

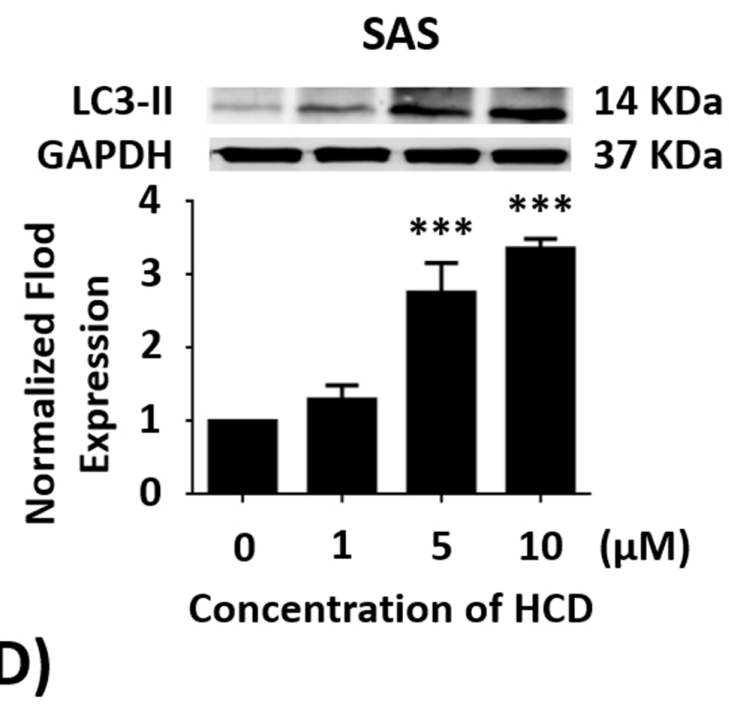

Figure 4: Altered protein levels of LC3-I and II of OECM1 and SAS cells treated with HCD. OECM1 and SAS cells were treated with 1, 5, and $10 \mu \mathrm{M}$ of HCD for $24 \mathrm{~h}$. Cells were lysed in RIPA buffer for the Western blot. Quantization of the expressions of (A and B) LC3-I and (C and D) LC3-II protein levels were performed, respectively. The results were presented as the mean \pm SE of three independent experiments. ${ }^{*} P<0.05, * * P<0.01$ and $* * * P<0.001$ when compared with the untreated control $(0 \mu \mathrm{M})$. 
9 are the key signal transducer in crosstalk of autophagy/ apoptosis which p53, capase-3, 6, and 9 can act as downregulators and Beclin-1 as an up-regulator [29]. Four stages of autophagic formation including initiation, nucleation, elongation, and maturation have been classified, Beclin-1 in nucleation stage as a critical role is activated by ULK-1 and forms protein complex with Vps34 and Vps15 proteins, which triggers formation of LC3 proteins and autophagosome [30]. In addition, Beclin-1-independent signal pathway is associated with PI3K-ClassIII and induces p62 activity [31], suggesting that Beclin-1-independent signal pathway is also involved in the activation of autophagy. Thereby the involvement Beclin-1-dependent and -independent pathways in the induction of autophagy is taken into consideration while HCD treatment resulted in the autophagy of OSCC cells with Beclin-1-dependent pathway. This issue is discussed in following section.

In the present study, the autophagic inhibition of HCD in two cell lines may act on different signal pathways. In OECM1 cells, mTOR, Beclin-1, and PI3KClassIII are decreased and AMPK is increased, while

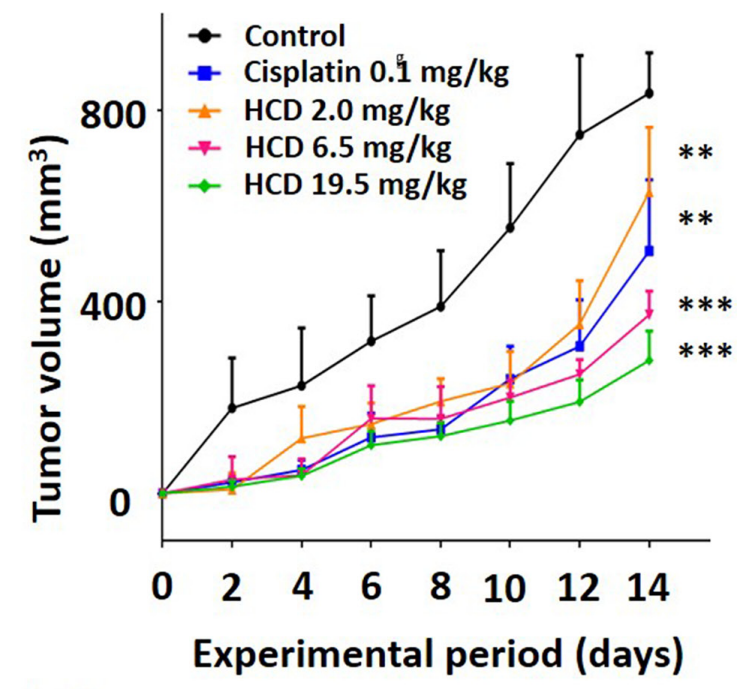

(A)
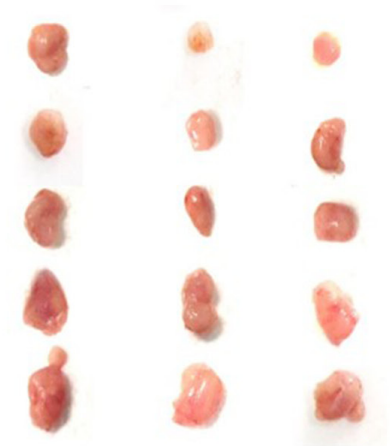

Cisplatin

Control

0.1

HCD

2.0

HCD HCD

cells

$\mathrm{mg} / \mathrm{kg}$

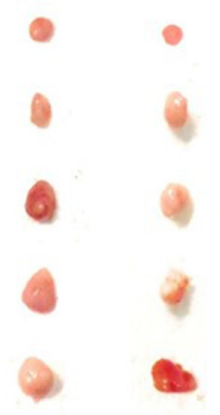

6.519 .5

(B)

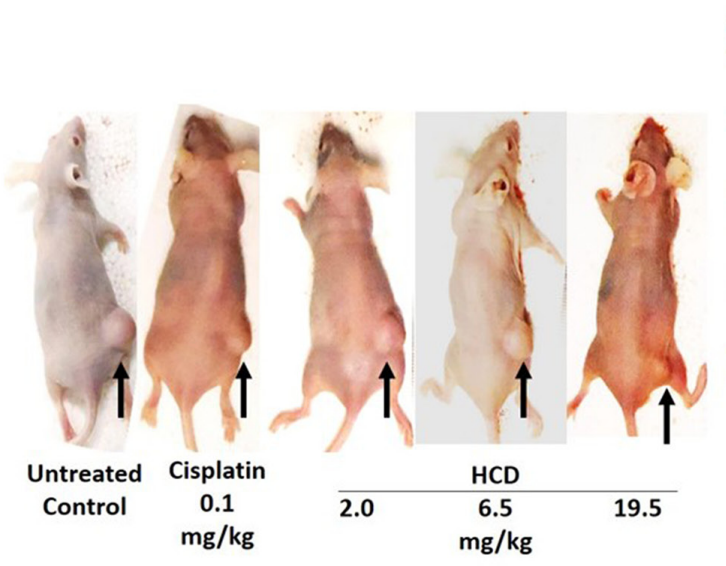

(gm)

(C)

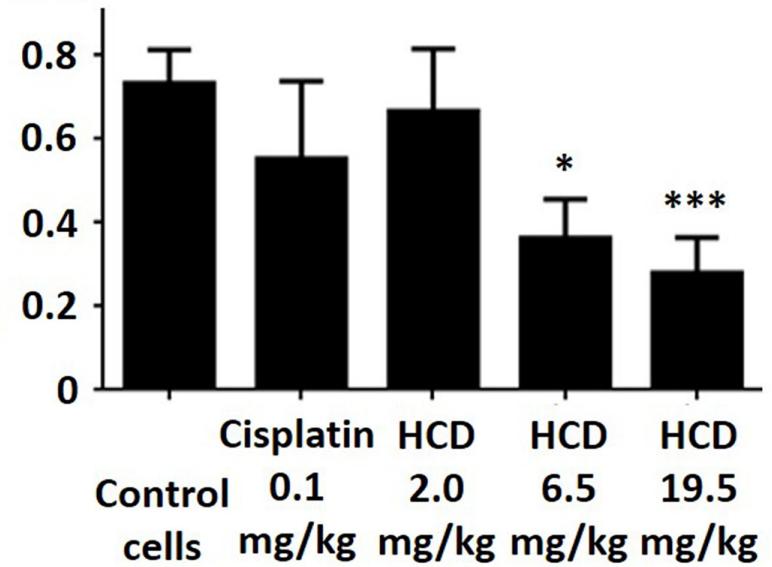

(D)

Figure 5: The xenograft tumor growth of SAS after treating with HCD and cisplatin. SAS cells were injected in nude mice and treated with $2.0,6.5$, and $19.5 \mathrm{mg} / \mathrm{kg}$ B.wt of $\mathrm{HCD}$ or $0.1 \mathrm{mg} / \mathrm{kg}$ B.wt of cisplatin. Tumor growth was observed via (A and B) tumor volume, (C) macroscopic observation, and (D) tumor weight. The results are presented as the mean $\pm \mathrm{SE}$ of six mice. ${ }^{*} P<0.05$, ${ }^{*} * P<0.01$ and $* * * P<0.001$ when compared with the untreated control $(0 \mu \mathrm{M})$. 
Beclin-1 and PI3K-ClassIII are decreased and AMPK is increased without change mTOR in SAS cells. There are two pathways, which are well known to regulate the autophagy. In response to starvation in mammalian cells: the class I PI3KClass-III/Akt/mTOR/p70S6K signaling pathway and the Ras/Raf/MEK/ERK1/2 pathway [32]. PI3K class III is activated through IGFRrelated signaling pathway and relays its signal to Akt [33]. Subsequently, Akt stimulates a central regulator of autophagy, mTOR. As diverse stimuli including energy deprivation presence, activities of $\mathrm{mTOR}$, and AMP activated protein kinase (AMPK) would be modulated

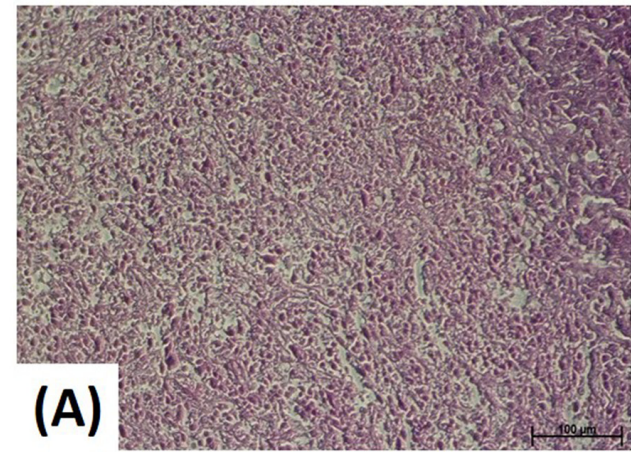

Control cells

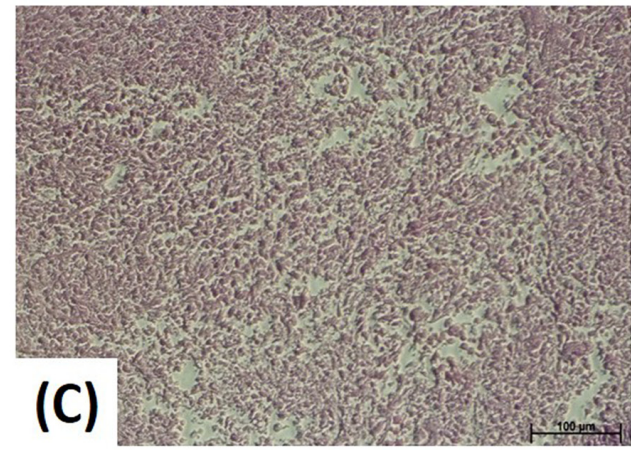

HCD $2.0 \mathrm{mg} / \mathrm{kg}$

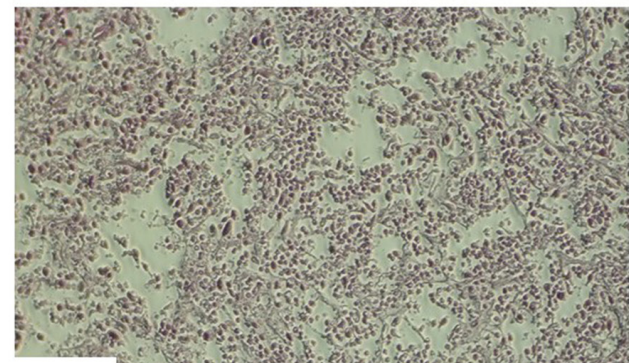

(E)

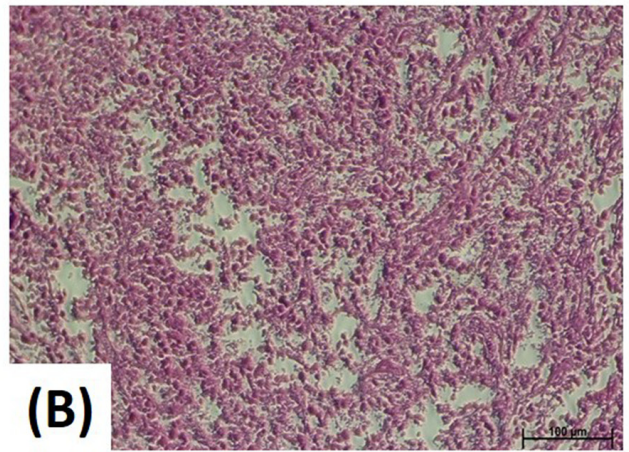

Cisplatin $0.1 \mathrm{mg} / \mathrm{kg}$

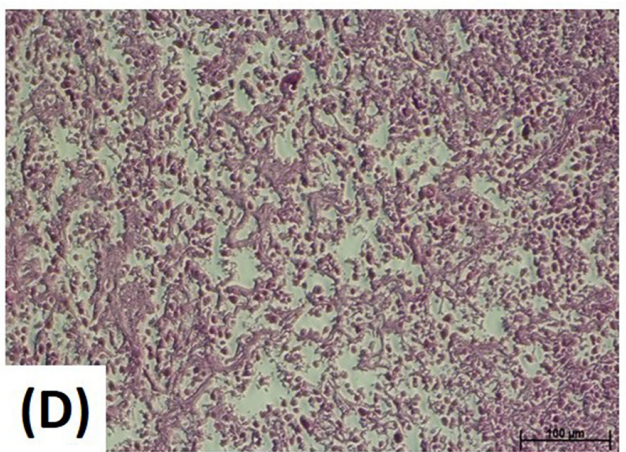

HCD $6.5 \mathrm{mg} / \mathrm{kg}$

\section{HCD $19.5 \mathrm{mg} / \mathrm{kg}$}

Figure 6: Histopathology of SAS xenograft tumor after treating with HCD and cisplatin. Xenograft tumor of SAS cells after treating with (B) $0.1 \mathrm{mg} / \mathrm{kg}$ B.wt cisplatin or (C) 2.0 , (D) 6.5 , and (E) $19.5 \mathrm{mg} / \mathrm{kg}$ B.wt of HCD were sliced and stained with hematoxylin and eosin. Tumor structure was observed and compared with the (A) untreated control $(0 \mu \mathrm{M})$. 
and consequently activated autophagy [34]. Western blot results showed HCD-induced autophagy in SAS cell was associated with the involvement of the mTOR/ PI3K-ClassIII/P62/Beclin-1/cyclin D signaling pathways (Figure 2B, 2D, and 2H; 3D and 3F). While the results showed HCD-induced autophagy in OECM1 cell was associated with the involvement of the mTOR/AMPK $\alpha /$ Akt/Beclin-1/cyclin D/LC3-I/LC3-II signaling pathways (Figure 2A and 2E; 3A, 3C, and 3E; 4A and 4C). On the other hand, the Ras/Raf/ERK pathway is among the most commonly deregulated pathways identified in tumors, as indicated by frequently observed activating mutations in Ras-mediated activation of Raf-Mek1 and ERK oncogenes [35]. Activated Ras-expressing cells are dependent on autophagy to survive during starvation [36]. In the most of the studies related to cell death, it was induced by the Ras/Raf/ERK pathway and ERK activation is unusually prolonged [37]. The prolonged ERK activation has been shown to promote the death of human cancer cell lines from different origins and this property of the Ras/Raf/ERK pathway to induce cell death could be used to target cancer cells [38]. ERK has also been shown to induce autophagy in response to a number of anti-tumor/cytotoxic agents, such as capsaicin in breast cancer cells and cadmium in mesangial cells [39]. According to the alterations of Ras/Raf/ERK pathway followed HCD incubation is not investigated in the present study and needs to be further explored. The important functions of Akt are associated with cell survival while Akt might suppress autophagy and apoptosis. The activation of Akt has been proposed to be a mechanism of autophagy suppression based on several observations [40]. The inhibition of Akt is associated with an increase mitochondrial superoxide and cellular reactive oxygen species (ROS) levels to cause the induction of apoptosis and autophagy [41]. Our findings indicate that the decrease of mTOR, PI3 kinase class III, Akt, and cyclin $\mathrm{D}$ levels are involved in cell death by HCD in OECM1 cells supports by previous results [41]. One study has been reported that Akt expression could down-regulate LC3-II expression, thereby inhibiting the autophagy [42]. The $\mathrm{Akt} / \mathrm{mTOR}$ pathway suppresses the autophagy, whereas

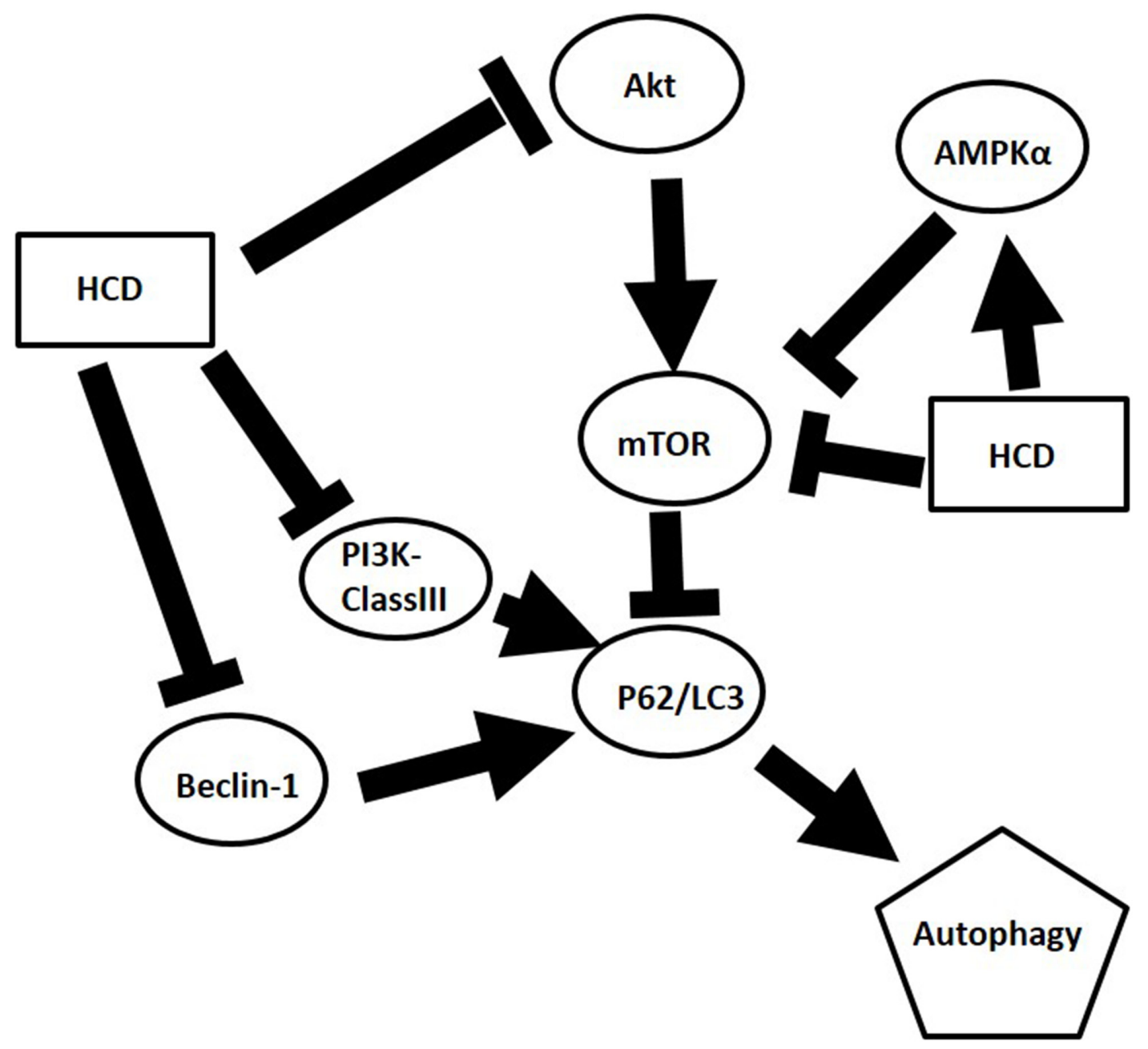

Figure 7: Graphic abstract of postulated mechanism of HCD in OSCC. 
Table 5: Primary and secondary antibodies used in this study

\begin{tabular}{lccc}
\hline Antibody & MW (kDa) & Dilution & Sources \\
\hline mTOR & 289 & $1: 1000$ & Cell Signalling \\
PI3K-ClassIII & 100 & $1: 1000$ & Cell Signalling \\
AMPKa & 62 & $1: 1000$ & Cell Signalling \\
P62 & 62 & $1: 1000$ & Cell Signalling \\
AKT & 60 & $1: 1000$ & Cell Signalling \\
Beclin-1 & 60 & $1: 1000$ & Cell Signalling \\
Cyclin D & 34 & $1: 1000$ & Cell Signalling \\
LC3-I & 16 & $1: 1000$ & Cell Signalling \\
LC3-II & 14 & $1: 1000$ & Cell Signalling \\
GADPH & 36 & $1: 10000$ & Cell Signalling \\
anti-Rabbit (IgG) & & $1: 5000$ & GeneTex \\
anti-Mouse (IgG) & & $1: 10000$ & GE
\end{tabular}

the ERK1/2 pathway positively potentiates the autophagy. These signaling pathways are often activated in numerous types of tumors and are associated with tumorigenesis. Therefore, in cancer cells, these signaling pathways likely play a significant role in regulating autophagy as well as in oncogenesis [43]. In this study revealed that HCD induced autophagy of OECM1 and SAS cells by LC3-mediated LC3-I/LC3-II/p62 pathway and consequently lead to the autophagic cell death.

Nowadays, xenograft mice model is an important approach in research of tumor biology and pharmacology. There are two main xenografts such as orthotopic and heterotopic injection/transplantation to meet those investigations demand. Thereby the experimental detail, especially the site of tumor transplantation, is challenged that it is directly related to reliability. Notably, orthotopic xenograft is more precise for examining the morphology of tumor growth and formation in situ to respond the accomplishment of therapy or treatment in exact cancer of patient. Conversely, the potentials of heterotopic transplantation such as easy handle and monitoring, immunocompetent host and non-immunogenic, and strong database support. However, there may have some limitations of heterotopic xenograft including (1) Heterotopic injection is lack of tumor/stroma interaction [44]. (2) In comparison with the microenvironment of orthotopic transplantation, local invasion and metastasis is less observed in heterotopic transplantation [45]. Obviously, heterotopic xenograft is easier tracing the tumor growth via Vernier scale to measure the size and volume of tumor without image monitor. Currently, this heterotopic xenograft is accepted and extensively performed by researchers and physicians for the drug discovery in cancer therapy. Heterologous with heterotopic xenograft in this study was executed as an animal model for the evaluation of anti-tumor efficacy of HCD. After HCD treatment resulted in shrinkage of tumor volume and size in heterotopic inoculated mice (Figure 5) possible due to tumor cell death, implying that HCD inhibited tumor growth. Nonetheless, recurrence is one critical issue in cancer treatment because the prognosis is associated with recurrent frequency. It has been elucidated that $\omega-6 / \omega-3$ fatty acid ratio in diet after surgery can modulate the recurrence of prostate cancer transplanted mice [46]. Moreover, CD-133-targeted nanoparticles conjugated with paclitaxel can inhibit xenograft tumor recurrence [47]. In our preliminary data revealed that the tumors of mice were recurrent when withdraw HCD treatment. Interestingly, the suppression of tumor size in tumor-mouse retreated with HCD was still observed (data not shown). The clinical application of HCD needs to be further elucidated.

Recently, HCD exhibits anti-cancer effect on neuroblastoma, glioma, and oral squamous cell lines, the application is still a challenge due to its low water solubility $[13,14]$. In order to amend this disadvantage, numerous novel approaches have been investigated such as nano-encapsulation. Nano-scale carriers have been extensively evaluated for promoting abovementioned problem and mesoporous silica nanoparticles (MSNs), one of nano-carrier can load/release drug directly via its pore channels and target to specific cells by functional surface [48]. Through these features, smart and biocompatible drug delivery system can be feasible for medical use such as chemotherapeutic drugs [49]. In solicitation of MSNconjugated drug delivery system, various therapeutic purposes such as cancer [50-54], ischemia [55], bacterial infections [56], others such as imaging [57, 58], and biomedical applications [59] have been elucidated. Remarkably, the applications of MSN conjugated with natural compounds such as quercetin in breast cancer 
[60], curcumin in breast cancer and colon cancer [61, 62], and resveratrol in colon cancer [63] have been tested in enhancement of bioavailability and solubility. These results are associated with MSN-HCD for upgrading HCD's potential and promise in clinical therapy [64].

In conclusion, the present results showed HCD could induce autophagic cell death through inhibiting MTOR and PI3K-classIII/Beclin-1 related signaling and activating AMPK $\alpha /$ P62/LC3-I/II signaling pathway in OSCC cells (Figure 7) but not in the normal cells-BEAS-2B cell line. Moreover, this autophagic cell death via HCD also inhibited xenograft OSCC tumor growth in nude mice. These results provide promising evidence that HCD has potential as a chemotherapeutic reagent for squamous cell carcinoma.

\section{MATERIALS AND METHODS}

\section{6-Hydroxycleroda-3,13-dien-15,16-olide (HCD) and cisplatin}

16-Hydroxycleroda-3,13-dien-15,16-olide (HCD) was extracted from the bark of $P$. longifolia as briefly described in a previous study [13]. (SP-4-2)diamminedichloroplatinum (II) (cisplatin, TEVA Pharma B.V., Haarlem, Netherlands) was taken as a positive control in this study.

\section{Cell culture}

Human gingival squamous carcinoma cell line OECM1 and tongue carcinoma cell line SAS were obtained from Dr. Ta-Chun Yuan (Department of Life Sciences, National Dong-Hwa University, Hualien, Taiwan) and human bronchus epithelial cell BEAS2B was obtained from Dr. Chih-Jen Yang (Department of Internal Medicine, Kaoshiung Medical University Hospital, Kaoshiung, Taiwan). All assays were carried out within 20 passages to ensure a uniform cell population and reproducibility.

OECM1 was cultured in RPMI 1640 medium (Thermo-Fisher, Waltham, USA) supplemented with $5 \%$ fetal bovine serum (FBS, Thermo-Fisher) and 1\% penicillin/streptomycin (PS, Thermo-Fisher), and SAS was cultured in Dulbecco's modified Eagle's medium (DMEM, Thermo-Fisher) supplemented with 5\% FBS and 1\% PS. BEAS-2B was cultured in DMEM supplemented with $10 \% \mathrm{FBS}$ and $1 \% \mathrm{PS}$. The cells were incubated in $\mathrm{CO}_{2}$ incubator (Thermo-Fisher). Incubation conditions were set as $37^{\circ} \mathrm{C}$ and the atmosphere at $5 \% \mathrm{CO}_{2}$. The medium was replaced every 2 days. As $80-90 \%$ confluence was reached, cells were detached by $0.25 \%$ trypsin/EDTA (Thermo-Fisher).

\section{MTT assay}

The MTT (3-(4, 5-dimethylthiazol-2-yl)-2, 5-diphenyltetrazolium bromide, Thermo-Fisher, Waltham,
USA) assay was used to analyze the viability of cells using the colorimetric method. The yellow tetrazolium salt reduced to a purple formazan was used to evaluate cell viability. $7 \times 10^{3} \mathrm{SAS} / \mathrm{OECM} 1$ cells were seeded in 96-well plates and were incubated overnight to allow cell confluence. Various concentration of $\operatorname{HCD}(0.5,1,5,10$, 20 , and $50 \mu \mathrm{M}$ for OECM1 and SAS; $1,5,10$, and 20 $\mu \mathrm{M}$ for BEAS-2B) and cisplatin $(5,10,20$, and $50 \mu \mathrm{M}$ for OECM1 and SAS; 10,20 , and $50 \mu \mathrm{M}$ for BEAS-2B) were added into the wells, respectively. The plates were incubated at $37^{\circ} \mathrm{C}$ for $24 \mathrm{~h}$. Then, $20 \mu \mathrm{L}$ of MTT was added and incubated at $37^{\circ} \mathrm{C}$ for 3-6 h. After incubation for 3-6 h, medium and MTT were removed, and formazan was solubilized using dimethyl sulfoxide, the absorbance of $570 \mathrm{~nm}$ was measured by EnSpire Alpha plate reader (PerkinElmer, Waltham, USA). The absorbance was positively correlated to the number of viable cells so that cell viability was represented as the percentage of absorbance between treated and untreated cells.

\section{Cell cycle analysis by flow cytometry}

$7 \times 10^{4}$ OECM1 and SAS cells were seeded per well in 12-well plates and were incubated overnight for cell adherence. Various concentrations of HCD and cisplatin were added and incubated for 12 and $24 \mathrm{~h}$, respectively. Next, cells were harvested by trypsin and fixed with $70 \%$ ethanol at $-20^{\circ} \mathrm{C}$ at least for $1 \mathrm{~h}$. The samples were washed in cold PBS twice, and then incubated with $1 \mathrm{~mL}$ $(\mathrm{v} / \mathrm{v})$ staining solution $(20 \mu \mathrm{g} / \mathrm{mL}$ of propidium iodide, $0.1 \%$ Triton $\mathrm{X}-100,0.2 \mathrm{mg} / \mathrm{mL}$ RNase) at $37^{\circ} \mathrm{C}$ for 30 $\mathrm{min}$. Finally, cells were analyzed by the flow cytometer (CytomicsTM FC500, Beckman, Fullerton, USA). Data from $10^{4}$ cells were collected for each data file.

\section{Western blotting}

$7 \times 10^{4}$ of OECM1 and SAS cells were seeded into 12 -well plate, when the cells reached about $80 \%$ confluence. OECM1 and SAS cells were treated with $\mathrm{HCD}$ for $24 \mathrm{~h}$, respectively. After incubation, media was removed and washed twice with PBS and then cells were homogenized using protein lysis solution (RIPA buffer). The samples were centrifuged at $12000 \times \mathrm{g}$ at $4^{\circ} \mathrm{C}$ for 30 min and the supernatant was kept at $-20^{\circ} \mathrm{C}$ until the assay. Interested proteins were separated using sodium dodecyl sulfate polyacrylamide gel electrophoresis (SDS-PAGE) and subsequently transferred to a PVDF (Millipore, Bedford, USA) membrane. The blots were blocked with 5\% non-fat milk in TBST saline $(20 \mathrm{mM}$ Tris-HCl, pH 7.4, $137 \mathrm{mM} \mathrm{NaCl}$, and $0.05 \%$ Tween-20) at room temperature for $1 \mathrm{~h}$ and then incubated with the appropriate primary antibody at $4{ }^{\circ} \mathrm{C}$ overnight. After wash, the blots were incubated with peroxidase conjugated secondary antibody for $1 \mathrm{~h}$. Then, the desired proteins were visualized by ECL reagents (GE Healthcare, Pittsburg, USA) for $1 \mathrm{~min}$, and LAS- 
3000 image system (FUJIFILM, Tokyo, Japan) was performed to detect protein signals. GAPDH was taken as an internal control for normalization. Table 5 lists the primary antibody and secondary antibodies.

\section{Animal model}

Six-week-old BALB/c nu/nu male mice $(n=30)$ were purchased from the National Laboratory Animal Center (Nan-Kang, Taiwan) and kept at controlled environmental conditions at room temperature $\left(22 \pm 2^{\circ} \mathrm{C}\right)$ with the humidity $(55 \pm 10 \%)$. The $12 \mathrm{~h}$ light (0600 am$1800 \mathrm{pm}$ ) and $12 \mathrm{~h}$ dark cycle was maintained throughout the study. The animals were fed a commercial diet and provided water ad libitum. The animal experimental protocols were followed as per the "Guide for the Care and Use of Laboratory Animals" of National DongHwa University approved by the National Dong-Hwa University Animal Ethics Committee. SAS cells $\left(8 \times 10^{5}\right.$ cells in $0.2 \mathrm{~mL}$ of DMEM) were subcutaneously injected into the right dorsal flank of nu/nu mice ( $\mathrm{n}=6$ per group). When tumor volume reached $0.6 \mathrm{~cm}^{3}$, they were randomly allotted into 3 groups: Control, Cisplatin $(0.1 \mathrm{mg} / \mathrm{kg} \mathrm{B.wt})$, and $\operatorname{HCD}(2.0,6.5$, and $19.5 \mathrm{mg} / \mathrm{kg} \mathrm{B.wt})$. Mice were intraperitoneally treated with $\mathrm{HCD}$ and cisplatin once every two days for a total of seven treatments. The body weight of inoculated tumor cell nude mice was measured once every two days. Tumor growth was measured twice weekly until sacrifice. The tumor volume was calculated based on the formula: $\left(\right.$ Length $\left.\times \mathrm{Width}^{2}\right) / 2$.

\section{Tissue and histopathology}

Mice were sacrificed by $\mathrm{CO}_{2}$ anesthesia and the tumors were excised immediately for measuring the tumor weights. One part of the tumor was weighed and the tissues were fixed in $4 \%$ formalin for histological analysis. The remainder of the tissue was immediately removed and stored at $-80^{\circ} \mathrm{C}$. The fixed tissue was dehydrated with alcohol and wax infiltration with Toluene: Paraffin (1:1, $\mathrm{v} / \mathrm{v}$ ) for $1 \mathrm{~h}$. Tissue was embedded for $30 \mathrm{~min}$ at $65^{\circ} \mathrm{C}$. Paraffin tissue sections were surface transverse sliced by the slicer (MICROM HM-325, Thermo-Fisher) into 5 $\mu \mathrm{m}$ of thickness. $5 \mu \mathrm{m}$ tissue sections were stained with hematoxylin and eosin stain (H \& E) (Sigma-Aldrich, St. Louis, USA). The completion of tissue sections was mounted with a coverslip after staining. Images were acquired using a phase contrast microscope (Carl Zeiss AG, Oberkochen, Germany) connected to a camera (Canon 700 D, Tokyo, Japan).

\section{Statistical analysis}

Data were expressed as mean $\pm \mathrm{SE}$ of at least three or more independent experiments. The results were analyzed by one-way analysis of variance (ANOVA) followed by a Tukey's test. Significant differences $(P<0.05)$ between the means of control and treatment were analyzed. All statistical procedures were performed with GraphPad Prism Ver 5.0 (GraphPad Software, La Jolla, USA).

\section{Abbreviations}

HCD, 16-hydroxycleroda-3, 13-dine-15, 16-olide; OSCC, oral squamous cell carcinoma; MTT, 3-(4, 5-dimethylthiazol-2-yl)-2, 5-diphenyltetrazolium bromide; H\&E, hematoxylin and eosin stain; mTOR, mammalian target of rapamycin; PI3K, phosphatidylinositol 3 kinase; AMPK, AMP activated protein kinase; ROS, reactive oxygen species; MSN, mesoporous silica nanoparticle; cisplatin, (SP-4-2)- diamminedichloroplatinum (II); FBS, fetal bovine serum; PS, penicillin/streptomycin; DMEM, Dulbecco's modified Eagle's medium; SDSPAGE, sodium dodecyl sulfate polyacrylamide gel electrophoresis; ANOVA, analysis of variance.

\section{Author contributions}

MFC, MJT, and CFW conceived and designed the experiments. YHC, $\mathrm{YCH}$, and SRL executed the experiments, acquisition and analysis of data. MFC, YSF, and CFW wrote the paper. All authors have read and proved this manuscript.

\section{ACKNOWLEDGMENTS}

The authors sincerely thank Prof. Max K Leong and Dr. Chun-Shu Lin who have given valuable suggestion.

\section{CONFLICTS OF INTEREST}

Authors declare that they have no known conflicts of interest associated with this publication and there has been no significant financial support for this work that could have influenced its outcome.

\section{FUNDING}

This work was supported by grants from the Major Science and Technology Special Project of China (1022320-B-259-001-3).

\section{REFERENCES}

1. Sciubba JJ. Oral cancer. The importance of early diagnosis and treatment. Am J Clin Dermatol. 2001; 2:239-251.

2. Olsen SM, Moore EJ, Koch CA, Kasperbauer JL, Olsen KD. Oral cavity and oropharynx squamous cell carcinoma with metastasis to the parotid lymph nodes. Oral Oncol. 2011; 47:142-144.

3. Marques LA, Eluf-Neto J, Figueiredo RA, Gois-Filho JF, Kowalski LP, Carvalho MB, Abrahao M, Wunsch-Filho V. 
Oral health, hygiene practices and oral cancer. Rev Saude Publica. 2008; 42:471-479.

4. Katkar K, Suthar A, Chauhan V. The chemistry, pharmacologic, and therapeutic applications of Polyalthia longifolia. Pharmacogn Rev. 2010; 4:62-68.

5. Mukherjee PK, Wahile A. Integrated approaches towards drug development from Ayurveda and other Indian system of medicines. J Ethnopharmacol. 2006; 103:25-35.

6. Chang FR, Hwang TL, Yang YL, Li CE, Wu CC, Issa $\mathrm{HH}$, Hsieh WB, Wu YC. Anti-inflammatory and cytotoxic diterpenes from formosan Polyalthia longifolia var. pendula. Planta Med. 2006; 72:1344-1347.

7. Murphy MM, Subramanyam M, Bindu MH, Annapurna J. Antimicrobial activity of clerodane diterpenoids from Polyalthia longifolia seeds. Fitoterapia. 2005; 76:336-339.

8. Sari DP, Ninomiya M, Efdi M, Santoni A, Ibrahim S, Tanaka K, Koketsu M. Clerodane diterpenes isolated from Polyalthia longifolia induce apoptosis in human leukemia HL-60 Cells. J Oleo Sci. 2013; 62:843-848.

9. Wu TH, Cheng YY, Chen CJ, Ng LT, Chou LC, Huang LJ, Chen YH, Kuo SC, El-Shazly M, Wu YC, Chang FR, Liaw CC. Three new clerodane diterpenes from Polyalthia longifolia var. pendula. Molecules. 2014; 19:2049-2060.

10. Shih YT, Hsu YY, Chang FR, Wu YC, Lo YC. 6-Hydroxycleroda-3,13-dien-15,16-olide protects neuronal cells from lipopolysaccharide-induced neurotoxicity through the inhibition of microglia-mediated inflammation. Planta Med. 2010; 76:120-127.

11. Lin YH, Lee CC, Chang FR, Chang WH, Wu YC, Chang JG. 16-hydroxycleroda-3,13-dien-15,16-olide regulates the expression of histone-modifying enzymes PRC2 complex and induces apoptosis in CML K562 cells. Life Sci. 2011; 89:886-895.

12. Lin $\mathrm{YH}$, Lee CC, Chan WL, Chang WH, Wu YC, Chang JG. 16-Hydroxycleroda-3,13-dien-15,16-olide deregulates PI3K and Aurora B activities that involve in cancer cell apoptosis. Toxicology. 2011; 285:72-80.

13. Thiyagarajan V, Lin SH, Chia YC, Weng CF. A novel inhibitor, 16-hydroxy-cleroda-3,13-dien-16,15-olide, blocks the autophosphorylation site of focal adhesion kinase (Y397) by molecular docking. Biochim Biophys Acta. 2013; 1830:4091-4101.

14. Thiyagarajan V, Sivalingam KS, Viswanadha VP, Weng CF. 16-hydroxy-cleroda-3,13-dien-16,15-olide induced glioma cell autophagy via ROS generation and activation of p38 MAPK and ERK-1/2. Environ Toxicol Pharmacol. 2016; 45:202-211.

15. Chen YH, Wang JY, Pan BS, Mu YF, Lai MS, So EC, Wong TS, Huang BM. Cordycepin enhances cisplatin apoptotic effect through caspase/MAPK pathways in human head and neck tumor cells. Onco Targets Ther. 2013; 6:983-998.

16. Azuma M, Tamatani T, Ashida Y, Takashima R, Harada $\mathrm{K}$, Sato M. Cisplatin induces apoptosis in oral squamous carcinoma cells by the mitochondria-mediated but not the NF-kappaB-suppressed pathway. Oral Oncol. 2003; 39:282-289.

17. Shen J, Huang C, Jiang L, Gao F, Wang Z, Zhang Y, Bai J, Zhou H, Chen Q. Enhancement of cisplatin induced apoptosis by suberoylanilide hydroxamic acid in human oral squamous cell carcinoma cell lines. Biochem Pharmacol. 2007; 73:1901-1909.

18. Huang AC, Lien JC, Lin MW, Yang JS, Wu PP, Chang SJ, Lai TY. Tetrandrine induces cell death in SAS human oral cancer cells through caspase activation-dependent apoptosis and LC3-I and LC3-II activation-dependent autophagy. Int J Oncol. 2013; 43:485-494.

19. Luo GX, Cai J, Lin JZ, Luo WS, Luo HS, Jiang YY, Zhang Y. Autophagy inhibition promotes gambogic acid-induced suppression of growth and apoptosis in glioblastoma cells. Asian Pac J Cancer Prev. 2012; 13:6211-6216.

20. Wu JJ, Quijano C, Chen E, Liu H, Cao L, Fergusson MM, Rovira II, Gutkind S, Daniels MP, Komatsu M, Finkel T. Mitochondrial dysfunction and oxidative stress mediate the physiological impairment induced by the disruption of autophagy. Aging (Albany NY). 2009; 1:425-437. https:// doi.org/10.18632/aging.100038.

21. White E, Karp C, Strohecker AM, Guo Y, Mathew R. Role of autophagy in suppression of inflammation and cancer. Curr Opin Cell Biol. 2010; 22:212-217.

22. Wang YF, Chang CJ, Chiu JH, Lin CP, Li WY, Chang SY, Chu PY, Tai SK, Chen YJ. NM23-H1 expression of head and neck squamous cell carcinoma in association with the response to cisplatin treatment. Oncotarget. 2014; 5:73927405. https://doi.org/10.18632/oncotarget.1912.

23. Shieh TM, Lin SC, Liu CJ, Chang SS, Ku TH, Chang KW. Association of expression aberrances and genetic polymorphisms of lysyl oxidase with areca-associated oral tumorigenesis. Clin Cancer Res. 2007; 13:4378-4385.

24. Kao SY, Chen YP, Tu HF, Liu CJ, Yu AH, Wu CH, Chang KW. Nuclear STK15 expression is associated with aggressive behaviour of oral carcinoma cells I and in vitro. J Pathol. 2010; 222:99-109.

25. Yang PY, Hsieh PL, Wang TH, Yu CC, Lu MY, Liao YW, Lee TH, Peng CY. Andrographolide impedes cancer stemness and enhances radio-sensitivity in oral carcinomas via miR-218 activation. Oncotarget. 2017; 8:4196-4207. https://doi.org/10.18632/oncotarget.13755.

26. Aggarwal S, Takada Y, Singh S, Myers JN, Aggarwal BB. Inhibition of growth and survival of human head and neck squamous cell carcinoma cells by curcumin via modulation of nuclear factor-kappaB signaling. Int J Cancer. 2004; 111:679-692.

27. Shinojima N, Yokoyama T, Kondo Y, Kondo S. Roles of the Akt/mTOR/p70S6K and ERK1/2 signaling pathways in curcumin-induced autophagy. Autophagy. 2007; 3:635-637.

28. Singletary K, Milner J. Diet, autophagy, and cancer: a review. Cancer Epidemiol Biomarkers Prev. 2008; 17:1596-1610. 
29. Radogna F, Dicato M, Diederich M. Cancer-type-specific crosstalk between autophagy, necroptosis and apoptosis as a pharmacological target. Biochem Pharmacol. 2015; 94:1-11.

30. Kang R, Zeh HJ, Lotze MT, Tang D. The Beclin 1 network regulates autophagy and apoptosis. Cell Death Differ. 2011; 18:571-580

31. Nikoletopoulou V, Markaki M, Palikaras K, Tavernarakis N. Crosstalk between apoptosis, necrosis and autophagy. Biochim Biophys Acta. 2013; 1833:3448-3459.

32. Han HY, Kim H, Jeong SH, Lim DS, Ryu MH. Sulfasalazine induces autophagic cell death in oral cancer cells via Akt and ERK pathways. Asian Pac J Cancer Prev. 2014; 15:6939-6944.

33. Yao F, Lv YC, Zhang M, Xie W, Tan YL, Gong D, Cheng HP, Liu D, Li L, Liu XY, Zheng XL, Tang CK. Apelin-13 impedes foam cell formation by activating Class III PI3K/ Beclin-1-mediated autophagic pathway. Biochem Biophys Res Commun. 2015; 466:637-643.

34. Mihaylova MM, Shaw RJ. The AMPK signalling pathway coordinates cell growth, autophagy and metabolism. Nat Cell Biol. 2011; 13:1016-1023.

35. Woessmann W, Chen X, Borkhardt A. Ras-mediated activation of ERK by cisplatin induces cell death independently of p53 in osteosarcoma and neuroblastoma cell lines. Cancer Chemother Pharmacol. 2002; 50:397-404.

36. Guo JY, Chen HY, Mathew R, Fan J, Strohecker AM, KarsliUzunbas G, Kamphorst JJ, Chen G, Lemons JM, Karantza V, Coller HA, Dipaola RS, Gelinas C, et al. Activated Ras requires autophagy to maintain oxidative metabolism and tumorigenesis. Genes Dev. 2011; 25:460-470.

37. Subramaniam S, Unsicker K. ERK and cell death: ERK1/2 in neuronal death. FEBS J. 2010; 277:22-29.

38. Cagnol S, Chambard JC. ERK and cell death: mechanisms of ERK-induced cell death--apoptosis, autophagy and senescence. FEBS J. 2010; 277:2-21.

39. Sridharan S, Jain K, Basu A. Regulation of autophagy by kinases. Cancers (Basel). 2011; 3:2630-2654.

40. Sarbassov DD, Guertin DA, Ali SM, Sabatini DM. Phosphorylation and regulation of Akt/PKB by the rictormTOR complex. Science. 2005; 307:1098-1101.

41. Degtyarev M, De Maziere A, Orr C, Lin J, Lee BB, Tien JY, Prior WW, van Dijk S, Wu H, Gray DC, Davis DP, Stern HM, Murray LJ, et al. Akt inhibition promotes autophagy and sensitizes PTEN-null tumors to lysosomotropic agents. J Cell Biol. 2008; 183:101-116.

42. Roy B, Pattanaik AK, Das J, Bhutia SK, Behera B, Singh P, Maiti TK. Role of PI3K/Akt/mTOR and MEK/ERK pathway in Concanavalin A induced autophagy in HeLa cells. Chem Biol Interact. 2014; 210:96-102.

43. Ellington AA, Berhow MA, Singletary KW. Inhibition of Akt signaling and enhanced ERK1/2 activity are involved in induction of macroautophagy by triterpenoid B-group soyasaponins in colon cancer cells. Carcinogenesis. 2006; 27:298-306
44. Kim MP, Evans DB, Wang H, Abbruzzese JL, Fleming JB, Gallick GE. Generation of orthotopic and heterotopic human pancreatic cancer xenografts in immunodeficient mice. Nat Protoc. 2009; 4:1670-1680.

45. Mognetti B, Di Carlo F, Berta GN. Animal models in oral cancer research. Oral Oncol. 2006; 42:448-460.

46. Kelavkar UP, Hutzley J, Dhir R, Kim P, Allen KG, McHugh K. Prostate tumor growth and recurrence can be modulated by the omega-6:omega-3 ratio in diet: athymic mouse xenograft model simulating radical prostatectomy. Neoplasia. 2006; 8:112-124.

47. Swaminathan SK, Roger E, Toti U, Niu L, Ohlfest JR, Panyam J. CD133-targeted paclitaxel delivery inhibits local tumor recurrence in a mouse model of breast cancer. $\mathrm{J}$ Control Release. 2013; 171:280-287.

48. Lee CH, Lin TS, Mou CY. Mesoporous materials for encapsulating enzymes. Nano Today. 2009; 4:165-179.

49. Wang Y, Zhao Q, Han N, Bai L, Li J, Liu J, Che E, Hu L, Zhang Q, Jiang T, Wang S. Mesoporous silica nanoparticles in drug delivery and biomedical applications. Nanomedicine. 2015; 11:313-327.

50. Huang IP, Sun SP, Cheng SH, Lee CH, Wu CY, Yang CS, Lo LW, Lai YK. Enhanced chemotherapy of cancer using $\mathrm{pH}$-sensitive mesoporous silica nanoparticles to antagonize P-glycoprotein-mediated drug resistance. Mol Cancer Ther. 2011; 10:761-769.

51. Lee CH, Cheng SH, Huang IP, Souris JS, Yang CS, Mou $\mathrm{CY}$, Lo LW. Intracellular $\mathrm{pH}$-responsive mesoporous silica nanoparticles for the controlled release of anticancer chemotherapeutics. Angew Chem Int Ed. 2010; 49:8214-8219.

52. Kankala RK, Kuthati Y, Liu CL, Mou CY, Lee CH. Killing cancer cells by delivering a nanoreactor for inhibition of catalase and catalytically enhancing intracellular levels of ROS. RSC Adv. 2015; 5:86072-86081.

53. Lin CH, Cheng SH, Liao WN, Wei PR, Sung PJ, Weng CF, Lee $\mathrm{CH}$. Mesoporous silica nanoparticles for the improved anticancer efficacy of cis-platin. Int J Pharm. 2012; 429:138-147.

54. Hung BY, Kuthati Y, Kankala R, Kankala S, Deng JP, Liu CL, Lee CH. Utilization of enzyme-immobilized mesoporous silica nanocontainers (IBN-4) in prodrugactivated cancer theranostics. Nanomaterials. 2015; 5:2169-2191.

55. Wang W, Sun X, Zhang H, Yang C, Liu Y, Yang W, Guo C, Wang C. Controlled release hydrogen sulfide delivery system based on mesoporous silica nanoparticles protects graft endothelium from ischemia-reperfusion injury. Int $\mathbf{J}$ Nanomedicine. 2016; 11:3255-3263.

56. Braun K, Pochert A, Lindén M, Davoudi M, Schmidtchen A, Nordström R, Malmsten M. Membrane interactions of mesoporous silica nanoparticles as carriers of antimicrobial peptides. J Colloid Interface Sci. 2016; 475:161-170. 
57. Du X, Li X, Xiong L, Zhang X, Kleitz F, Qiao SZ. Mesoporous silica nanoparticles with organo-bridged silsesquioxane framework as innovative platforms for bioimaging and therapeutic agent delivery. Biomaterials. 2016; 91:90-127.

58. Friedman R. Nano dot technology enters clinical trials. J Natl Cancer Inst. 2011; 103:1428-1429.

59. Wang X, Li W. Biodegradable mesoporous bioactive glass nanospheres for drug delivery and bone tissue regeneration. Nanotechnology. 2016; 27:225102.

60. Sarkar A, Ghosh S, Chowdhury S, Pandey B, Sil PC. Targeted delivery of quercetin loaded mesoporous silica nanoparticles to the breast cancer cells. Biochim Biophys Acta. 2016; 1860:2065-2075.

61. Kim S, Diab R, Joubert O, Canilho N, Pasc A. Core-shell microcapsules of solid lipid nanoparticles and mesoporous silica for enhanced oral delivery of curcumin. Colloids Surf B Biointerfaces. 2016; 140:161-168.

62. Bollu VS, Barui AK, Mondal SK, Prashar S, Fajardo M, Briones D, Rodriguez-Dieguez A, Patra CR, Gomez-Ruiz S. Curcumin-loaded silica-based mesoporous materials: Synthesis, characterization and cytotoxic properties against cancer cells. Mater Sci Eng C Mater Biol Appl. 2016; 63:393-410.

63. Summerlin N, Qu Z, Pujara N, Sheng Y, Jambhrunkar S, McGuckin M, Popat A. Colloidal mesoporous silica nanoparticles enhance the biological activity of resveratrol. Colloids Surf B Biointerfaces. 2016; 144:1-7.

64. Thiyagarajan V, Lin SX, Lee $\mathrm{CH}$, Weng CF. A focal adhesion kinase inhibitor 16-hydroxy-cleroda-3,13-dien16,15-olide incorporated into enteric-coated nanoparticles for controlled anti-glioma drug delivery. Colloids Surf B Biointerfaces. 2016; 141:120-131. 